\title{
Ecotypic differentiation of native rainbow trout (Oncorhynchus mykiss) populations from British Columbia
}

\author{
E.R. Keeley, E.A. Parkinson, and E.B. Taylor
}

\begin{abstract}
We sampled 34 native rainbow trout (Oncorhynchus mykiss) populations over a wide geographic area of British Columbia to determine whether variation in morphology is related to differences in habitat or fish community characteristics experienced by a population. After correcting for differences in body size, the most dramatic differences occurred in external characteristics between stream- and lake-dwelling populations. Rainbow trout from streams had more robust bodies with larger caudal peduncles and heads and longer paired fins than rainbow trout from lakes. Unlike other lake populations, piscivorous rainbow trout populations had relatively large heads and mouths that were more similar in size to those of stream-dwelling populations. We found fewer differences in the size of internal organs across ecotypes, producing little predictive ability of these characteristics to differentiate populations of rainbow trout. We also sampled 27 additional rainbow trout populations with unknown fish communities to determine how well large-scale patterns predict morphological differentiation over a smaller spatial scale. Of the five ecotypes that we detected at a smaller scale, the largest differences again occurred between stream and lake populations. Our data suggest that external morphological variation among populations of rainbow trout covaries with ecological conditions at a variety of spatial scales, particularly between lakes and rivers.
\end{abstract}

Résumé : Nous avons échantillonné 34 populations indigènes de truites arc-en-ciel (Oncorhynchus mykiss) dans une grande région géographique de la Colombie-Britannique afin de déterminer si la variation morphologique est reliée à des différences d'habitat ou des caractéristiques des communautés de poissons rencontrées par la population. Après correction pour les différences de taille, les différences les plus spectaculaires existent entre les caractéristiques externes des populations des cours d'eau et celles des lacs. Les truites arc-en-ciel des cours d'eau ont un corps plus robuste avec un pédoncule caudal et une tête plus grands et de plus longues nageoires paires que les truites des lacs. Contrairement aux autres populations des lacs, les truites arc-en-ciel piscivores ont une tête et une bouche relativement plus grandes, de taille plus semblable à celles des populations habitant les cours d'eau. Il existe moins de différences entre les écotypes en ce qui concerne la taille des organes internes et ces caractéristiques n'ont qu'un faible pouvoir de prédiction pour distinguer les populations de truites arc-en-ciel. Nous avons aussi échantillonné 27 populations additionnelles de truites arc-en-ciel appartenant à des communautés de poissons inconnues afin de vérifier dans quelle mesure les patterns à grande échelle permettent de prédire la différentiation morphologique sur une échelle spatiale réduite. Des cinq écotypes reconnus à plus petite échelle, les différences les plus accentuées se produisent encore entre les populations des cours d'eau et celles des lacs. Nos données laissent croire que la variation morphologique externe de la truite arc-en-ciel est en covariation avec les conditions écologiques à plusieurs échelles spatiales, particulièrement entre les lacs et les rivières.

[Traduit par la Rédaction]

\section{Introduction}

Intraspecific variation in phenotypic traits has been repeatedly demonstrated among populations in a variety of plant and animal species, and much of this variability appears to represent adaptation to local conditions (Sultan
1995; Smith and Skùlason 1996). Turesson (1922) was the first to coin the term "ecotype" to describe geographical isolates of plants that were consistently associated with particular environmental or habitat characteristics as a result of selection in those environments (e.g., alpine ecotype). Such variability has not only been an essential component of stud-

Received 14 June 2004. Accepted 4 February 2005. Published on the NRC Research Press Web site at http://cjfas.nrc.ca on 9 July 2005.

J18181

E.R. Keeley. ${ }^{1}$ Department of Biological Sciences, Box 8007, Idaho State University, Pocatello, ID 83209, USA.

E.A. Parkinson. British Columbia Ministry of Water, Land and Air Protection, 2204 Main Mall, The University of British Columbia, Vancouver, BC V6T 1Z4, Canada.

E.B. Taylor. Department of Zoology, Biodiversity Research Centre, and Native Fishes Research Group, The University of British Columbia, 6270 University Boulevard, Vancouver, BC V6T 1Z4, Canada.

${ }^{1}$ Corresponding author (e-mail: keelerne@isu.edu). 
ies of the evolutionary origin of geographic variation (Mayr 1963; Gould and Johnston 1972) but is also increasingly viewed as essential in biodiversity conservation (e.g., Crandall et al. 2000). Effective conservation strategies need to maintain this diversity to ensure that the full evolutionary potential of a species is protected, especially as a buffer against extinction in the face of environmental change (Scudder 1989; Fraser 2000). Empirical mapping of this information for every population of every species is, however, clearly impossible. In this paper, we explore a method of predicting patterns of potentially adaptive variation among populations of rainbow trout (Oncorhynchus mykiss) using a variety of existing information for north-temperate salmonid fishes. We then test this methodology by measuring a series of morphological traits of rainbow trout from native populations over a wide geographic area. Our second objective is use these data to draw some general conclusions concerning the patterns of adaptive radiation that might be expected to occur among isolated populations of freshwater fish.

Our predictions of patterns of morphological variation are based on three types of information. First, breeding studies have established the genetic basis for a variety of phenotypic traits in both rainbow trout and closely related species. Second, correlations between phenotypic traits and habitat variation, among both species and populations of freshwater fishes, suggest that many of these traits are adaptive (Robinson and Parsons 2002). Finally, our ability to extend our predictions to the entire species range depends on large, integrated databases that contain a variety of physical, chemical, and biological information about individual water bodies. Our data set is an extension of previous studies that have focused on detailed comparisons of a limited number of populations or variation in a few traits over many populations (Schluter and McPhail 1993; Taylor 1999).

If ecological conditions experienced by different populations of rainbow trout are important in selecting for phenotypic characteristics, our most general prediction was that morphological variation would not be randomly associated with environmental variation, but rather, it would be consistently correlated with variation in habitat or community structure. Specifically, we made a number of predictions related to three general areas of ecological morphology that have been used to infer adaptation in other systems: feeding, locomotion, and organ size. Although distinct ecotypes have been documented in a number of northern fish taxa (Robinson and Wilson 1994; Taylor 1999), diversity appears to be especially high in salmonids (Taylor 1991, 1999). In particular, rainbow trout in British Columbia are a good model species for our study because of their diverse suite of life histories, multiple phylogenetic groups with distinct evolutionary histories, and diversity of habitats and communities in which they are found (Taylor and Haas 1996; McCusker et al. 2000).

Morphological adaptations associated with feeding specialization appear to be common in north-temperate freshwater fish, including the salmonids. In comparisons among species and populations, larger diet items are associated with shorter and more widely spaced gill rakers, larger mouths, and larger heads. These types of differences have been repeatedly demonstrated among planktivore, insectivore, and piscivore diet specialists. Piscivores have large mouths for a given body size in comparison with nonpiscivorous species (Wainwright and Richard 1995). Among lake populations, the presence of benthic competitors such as catostomid fish appears to cause brook trout (Salvelinus fontinalis) to shift to a planktivorous diet with a feeding morphology of more narrowly spaced gill rakers (Magnan 1988). In contrast, the presence of plankton-feeding specialists has been associated with shifts by sympatric species to a more benthically oriented diet and with a change to shorter, more widely spaced gill rakers (Lindsey 1981). If the presence or absence of either type of competitor has a significant influence on shaping rainbow trout phenotypes, then this too should be reflected in their morphological characteristics.

Morphological characteristics associated with swimming ability are also thought to be influenced by different habitat conditions. For instance, salmonids that live in fast-flowing stream habitats tend to have longer fins and a more robust body than slow-flowing stream or lake-inhabiting populations (Swain and Holtby 1989; Pakkasmaa and Piironen 2001; Imre et al. 2002). The genetic basis for such variation has been verified in at least some salmonids (e.g., Riddell et al. 1981; Taylor and McPhail 1985).

Variation in habitat characteristics may also be related to the relative size of internal organs. Although we know of no similar comparison for most organs in a species of fish, studies of seabirds indicate that the size of organs can vary dramatically among populations of the same species, some of which may be a result of adaptation to local conditions (Hilton et al. 2000). For instance, metabolic supply and processing organs, such as liver and pyloric caeca, may be relatively large under circumstances where individuals can allocate a greater proportion of their acquired energy intake to somatic growth instead of activity (Bergot et al. 1981; Magnan and Stevens 1992). Similarly, a larger heart muscle is expected in populations that have relatively high activity levels (Farrell et al. 1990). In our study, we predicted stream populations of rainbow trout that must actively swim against a current to have relatively large heart sizes for a given body size. In contrast with processing and circulatory organs, the size of digestive organs has been examined extensively in fishes. Herbivorous and omnivorous fish species, which exploit a food source with a relatively low energy density, tend to have a larger gut size than piscivorous species that feed on prey with a high energy density (Fryer and Iles 1972; Kramer and Bryant 1995). Hence, piscivorous rainbow trout populations were predicted to have relatively small intestines compared with omnivorous populations.

To test our predictions, we devised a sampling program to compare replicate rainbow trout populations from eight putative ecotypic categories that were selected based on habitat characteristics or the composition of fish species present. We used populations from British Columbia, Canada, because this area represents a core of the natural distribution for this species that also has numerous populations that are unaffected by artificial stocking. We established three of these ecotypes based on observations of past researchers, which include large-lake "piscivores" (Irvine 1978), "headwater" (stream) populations (Northcote and Hartman 1988), and "anadromous" populations, commonly referred to as steelhead trout (Withler 1966; Smith 1969). In addition to the first two stream-dwelling ecotypes (headwater and anadro- 
mous populations), we also included a "large river" ecotype representing populations that achieve a relatively large body size at maturity but do not have access to the ocean (Northcote 1997). Because competition is thought to be an important force in driving differentiation (Magnan 1988; Schluter and McPhail 1993; Robinson and Wilson 1994), we also compared rainbow trout populations from lakes with different combinations of competitors. As a basis of comparison, we sampled lakes where rainbow trout were the only fish species present (solitary populations) as well as populations with different combinations of competitors. Hence, three types of mixed species lakes were included in our ecotypic comparisons. We sampled rainbow trout populations that only co-occur with either a sucker species (Catostomidae) as a benthos competitor (mixed 1) or a minnow species (Cyprinidae) as a plankton and benthos competitor (mixed 2) as well as populations with both types of competitors (mixed 3).

Finally, we also examined rainbow trout populations over a smaller scale by sampling interconnected streams and lakes within replicate watersheds. We compared the results from the large and small spatial scales to determine whether differences across large spatial scales can be used to predict differences at local scales where population and habitat characteristics are less well known. Given the growing and widespread threats of extinction in many ecosystems, our study provides a method of mapping biodiversity at the intraspecific level using ecologically based hypotheses and the knowledge of the aquatic landscape that each population inhabits.

\section{Methods and materials}

We attempted to sample at least three replicate populations of each of the eight putative ecotypes across a wide geographic area (Fig. 1a). The ecotypes sampled were solitary, piscivorous, mixed 1 , mixed 2 , and mixed 3 lake populations as well as headwater, large river, and anadromous stream populations (Table 1). We sampled over two different geographic scales. Our initial sample of 34 populations spanned $600000 \mathrm{~km}^{2}$ of British Columbia, while our second level of sampling involved 27 populations within the Nechako River watershed covering about $2000 \mathrm{~km}^{2}$ (Fig. 1b). We initiated our search for populations that had a specific composition of fish species by using a database that provides a list of species present in water bodies across British Columbia (http://www.bcfisheries.gov.bc.ca/fishinv). Because we were only interested in examining natural populations, we also used the database to eliminate rainbow trout populations that had been established by artificial stocking or had been repeatedly stocked with rainbow trout from nonnative populations. We used this initial list to identify potential sample sites and we then queried regional government biologists to determine whether our species list was correct and whether populations had been artificially established or supplemented but were unreported in the database.

To collect the full range of age-classes present in each population, we used a variety of techniques to capture rainbow trout. In streams that had a maximum depth of less than $1 \mathrm{~m}$, we used a backpack electroshocker to sample fish up to $30 \mathrm{~cm}$. In larger streams or rivers that had age-classes of fish that occupied habitats too deep to be reached by someone wading with an electroshocker, we collected individuals by angling. In lake populations, we collected individuals by using a monofilament gill net or by angling. Each of $135-\mathrm{m}$ gill nets consisted of $15-\mathrm{m}$ panels of netting that varied in mesh size from 1.3 to $9 \mathrm{~cm}$. By using a multipanel net, we were able to collect fish down to $5 \mathrm{~cm}$ in length as well as the largest individuals in the population. In addition, we used a $2 \mathrm{~m}$ by $25 \mathrm{~m}$ beach seine, with $5-\mathrm{mm}$ mesh, to encircle and capture smaller individuals found in the littoral region of a lake. In most lake populations, we captured 50 individual rainbow trout distributed across as many ageclasses as we could capture. In populations with a narrow range of age- and size-classes, we limited our sample to 35 individuals.

We held all captured individuals in a holding container with fresh water until we measured each fish for fork length $( \pm 1 \mathrm{~mm})$ and mass $( \pm 0.01 \mathrm{~g})$, collected a scale sample for aging and a tissue sample stored in $95 \%$ ethanol for archiving and DNA analysis (P. Tamkee and E.B. Taylor, Department of Zoology, The University of British Columbia, Vancouver, British Columbia, unpublished data), and then attached a unique identification tag to each fish. We euthanized fish before collecting size measurements and then finally placed individuals in preservative (10\% formalin) for later morphometric analyses. In the laboratory, we measured external morphological characteristics using a digital caliper $( \pm 0.01 \mathrm{~mm})$ connected to a microcomputer that compiled all measurements electronically. We selected a suite of external morphological features that reflected characteristics of the fish that we hypothesized would be selected for under different ecotypic conditions (Fig. 2). For comparing differences in feeding morphology, we used measurements of mouth, eye, and head dimensions, whereas swimming morphology was assessed by comparing differences in paired fin length, caudal peduncle depth, and body depth (Boily and Magnan 2002). We calculated average gill raker spacing and length for each individual by removing the left-most gill arch and measuring the length and distance between all rakers on the arch with a dissecting microscope. To assess ecotypic differences in internal organ investment, we measured the mass of heart, liver, pyloric caeca, stomach, and intestine. We measured the mass of internal organs of the preserved fish by clipping off the esophagus and circulatory system at the level of the esophageal sphincter and removing the viscera from the body cavity. We separated individual organs and any fatty tissue from each other and then weighed each organ on an electronic balance $( \pm 0.0001 \mathrm{~g})$. The heart was separated from the circulatory system by clipping off the organ at the narrowing of the bulbous arteriosus or the origin of the ventral aorta and removing it from the pericardial sac. The intestine was clipped off from the lower region of the stomach at the pyloric sphincter and any contents were removed before being weighed. The liver and pyloric caeca were cut from the point of attachment to the viscera, whereas the gonads were separated at the point of attachment to the mesonephric duct. All measurements were made on moist specimens that had excess water removed by momentarily blotting organs with a paper towel.

\section{Statistical analyses}

To correct for size-related differences across individuals and populations, we regressed each morphological character- 
Fig. 1. (a) Geographic locations of 34 rainbow trout (Oncorhynchus mykiss) populations included in the large-scale comparison of trout morphology. Numbers 1-34 identify the populations and correspond to those listed in Appendix A. The hatched box depicts the area represented in Fig. 1b. The inset map identifies the location of British Columbia within the native distribution (shaded area) of rainbow trout in North America. (b) Geographic locations of 27 rainbow trout populations from interconnected lakes and streams used in the small-scale comparisons examining trout morphology. Numbers 35-61 identify the populations and correspond to those listed in Appendix A.

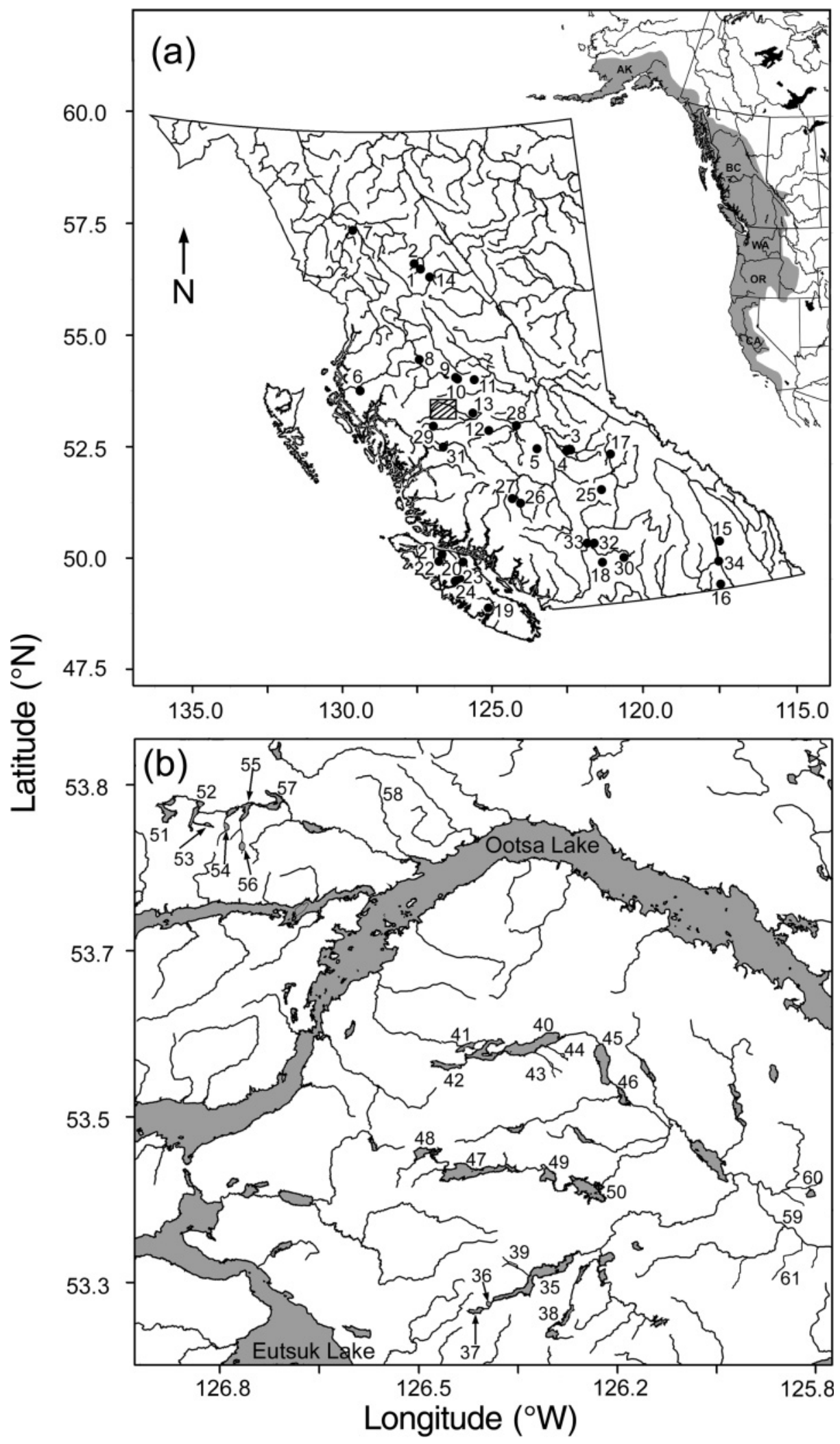


Table 1. Ecotypic categories and defining criteria used in comparing rainbow trout (Oncorhynchus mykiss) morphology from British Columbia lakes and streams.

\begin{tabular}{|c|c|c|c|}
\hline Ecotype & Habitat type & Ecological criteria & Reference $(\mathrm{s})^{a}$ \\
\hline Solitary & Lake & Rainbow trout only fish species present & Bourke et al. 1999 \\
\hline Mixed 1 & Lake & $\begin{array}{l}\text { Rainbow trout with benthivorous fish species present } \\
\text { (Catostomidae) }\end{array}$ & Magnan 1988 \\
\hline Mixed 3 & Lake & $\begin{array}{l}\text { Rainbow trout with planktivorous and benthivorous fish } \\
\text { species present }\end{array}$ & Magnan 1988; Johannes and Larkin 1961 \\
\hline Headwater & Stream & First-order stream located above a movement barrier & Northcote and Hartman 1988 \\
\hline Large river & Stream & $\begin{array}{l}\text { Fifth-order stream or larger located above a fish move- } \\
\text { ment barrier }\end{array}$ & Northcote 1997 \\
\hline Anadromous & Stream & $\begin{array}{l}\text { Population that migrates between a freshwater and } \\
\text { marine habitat }\end{array}$ & Withler 1966; Smith 1969 \\
\hline
\end{tabular}

${ }^{a}$ Past studies that have noted putative ecotypes for rainbow trout or morphological or ecological differentiation for a similar species of salmonid fish.

Fig. 2. Position of the landmarks used to measure the size of rainbow trout (Oncorhynchus mykiss) morphological features. Features are defined as follows: 1-2, premaxilla length; 1-3, head length; 4-5, pectoral fin length; 6-7, pelvic fin length; 8-9, caudal peduncle depth; $10-11$, body depth; 12-13, eye diameter. Other morphological measures not shown include head width (the distance between the left and right side of the head measured at the center of the opercula), mouth width (the internal breadth of the mouth measured proximate to point 2 on either side of the buccal cavity), and gill raker length and spacing.

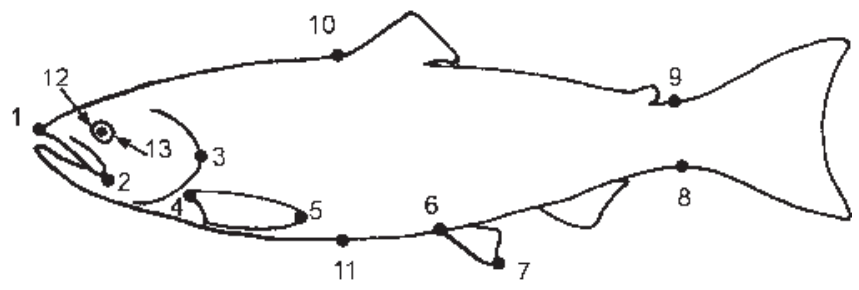

istic against fork length. All measurements were $\log _{10}$ transformed to ensure that we met the assumption of homogeneity of variance, and we visually examined the residuals from all analyses by plotting them against body size to ensure that we met this assumption. Because of the large number of pairwise comparisons of slopes, we could not assume that the slope describing the relationship between morphological traits and body size was equal across all populations. We used the population or separate withingroup slope to adjust each trait to a common body size based on the method of Thorpe (1976). We calculated size-adjusted measurements for internal organs in the same manner except that we used the mass of organs regressed against fish body mass to calculate the slope used to estimate the size-adjusted trait.

Based on our preliminary survey of government databases, we identified and sampled a target of three populations from each of the eight ecotypes. We discovered, however, that in some cases, the species composition was slightly different from that recorded in the databases. Some lake populations had more species present than anticipated, resulting in more than three populations in some mixed species lake ecotypes. We were also able to identify and sample only two popula- tions of two categories that contained rainbow trout with one other fish species: rainbow trout with a sucker species or rainbow trout with a minnow species. In all other categories, we obtained at least three populations of each ecotype (Fig. 1a; Appendix A).

To assess overall morphological differences between ecotypes, we used a multivariate analysis of variance (MANOVA) for size-adjusted external features (including gill raker length and spacing) and a separate MANOVA for internal organs that were also size adjusted. In our MANOVA models, we used ecotype as one independent variable and population nested within ecotype as a second variable to determine whether our approach of using a population as a unit of observation provided meaningful comparisons even after controlling for variability among individuals within populations. To provide an objective summary of correlated differences across rainbow trout populations, we performed a principal component analysis (PCA) of correlation matrices on the size-adjusted data to determine whether morphological variation in swimming, feeding, and organ size was related to ecotypic variation (Fleming et al. 1994). We only considered PCs with eigenvalues greater than 1 (Quinn and Keough 2002). When rotation of principal axes improved their interpretation, we used a promax rotation method (SAS Institute Inc. 1999). We compared variation in PC scores with a nested analysis of variance (ANOVA) to determine whether a significant proportion was accounted for by ecotypic differences or by populations nested within ecotypes. For nested ANOVA computations, we used the mixed-model procedure (proc mixed) with ecotype as a fixed effect and population as a random effect in SAS version 8.02, which employs a restricted maximum likelihood estimation (SAS Institute Inc. 1999) to evaluate the effect of population nested within ecotype. Tests of significance for random effects in nested ANOVA models were based on the likelihood ratio (LR) statistic (Littell et al. 1996). To calculate the variance components in nested models, we used the general linear model procedure (proc glm) for fixed effects and the variance component procedure (proc varcomp) for random effects (SAS Institute Inc. 1999). All ecotypic comparisons (fixed effects) were based on the variation remaining after statistically controlling for the effect of population 
Table 2. Results from univariate nested ANOVA for 11 morphological characteristics of rainbow trout (Oncorhynchus mykiss), comparing the variation accounted for among populations nested within ecotypes or among ecotypes.

\begin{tabular}{|c|c|c|c|c|c|}
\hline \multirow[b]{2}{*}{ Morphological trait } & \multirow[b]{2}{*}{ Variance component } & \multicolumn{2}{|c|}{ Large-scale variation } & \multicolumn{2}{|c|}{ Small-scale variation } \\
\hline & & $\begin{array}{l}\% \text { of total } \\
\text { variation }\end{array}$ & $P$ & $\begin{array}{l}\% \text { of total } \\
\text { variation }\end{array}$ & $P$ \\
\hline \multirow[t]{2}{*}{ Caudal peduncle depth } & Among populations within ecotypes & 19.7 & 0.0005 & 40.9 & 0.0001 \\
\hline & Among ecotypes & 28.8 & 0.0001 & 6.92 & 0.42 \\
\hline \multirow{2}{*}{ Body depth } & Among populations within ecotypes & 33.7 & 0.0003 & 30.8 & 0.0001 \\
\hline & Among ecotypes & 26.6 & 0.0011 & 7.95 & 0.22 \\
\hline \multirow[t]{2}{*}{ Pectoral fin length } & Among populations within ecotypes & 21.8 & 0.0004 & 44.9 & 0.0001 \\
\hline & Among ecotypes & 37.8 & 0.0001 & 27.1 & 0.0098 \\
\hline \multirow[t]{2}{*}{ Pelvic fin length } & Among populations within ecotypes & 25.8 & 0.0004 & 26.8 & 0.0001 \\
\hline & Among ecotypes & 35.0 & 0.0001 & 28.1 & 0.0004 \\
\hline \multirow[t]{2}{*}{ Head length } & Among populations within ecotypes & 31.1 & 0.0003 & 35.1 & 0.0001 \\
\hline & Among ecotypes & 20.5 & 0.011 & 28.9 & 0.0001 \\
\hline \multirow[t]{2}{*}{ Head width } & Among populations within ecotypes & 23.2 & 0.0004 & 26.5 & 0.0001 \\
\hline & Among ecotypes & 19.2 & 0.0016 & 42.4 & 0.0001 \\
\hline \multirow[t]{2}{*}{ Mouth width } & Among populations within ecotypes & 24.5 & 0.0004 & 25.8 & 0.0001 \\
\hline & Among ecotypes & 30.3 & 0.0001 & 24.3 & 0.0009 \\
\hline \multirow[t]{2}{*}{ Premaxilla length } & Among populations within ecotypes & 24.8 & 0.0004 & 44.5 & 0.0001 \\
\hline & Among ecotypes & 32.1 & 0.0001 & 24.7 & 0.016 \\
\hline \multirow[t]{2}{*}{ Eye diameter } & Among populations within ecotypes & 36.6 & 0.0003 & 61.7 & 0.0001 \\
\hline & Among ecotypes & 52.9 & 0.0001 & 22.2 & 0.074 \\
\hline \multirow[t]{2}{*}{ Gill raker length } & Among populations within ecotypes & 18.2 & 0.0006 & 40.6 & 0.0001 \\
\hline & Among ecotypes & 17.8 & 0.0007 & 0.6 & 0.98 \\
\hline \multirow[t]{2}{*}{ Gill raker spacing } & Among populations within ecotypes & 80.0 & 0.0002 & 33.3 & 0.0001 \\
\hline & Among ecotypes & 11.5 & 0.68 & 9.2 & 0.15 \\
\hline
\end{tabular}

Note: Large-scale variation refers to 34 populations sampled across British Columbia, and small-scale variation refers to 27 populations sampled within a single watershed. All traits were adjusted to a common body size of $179 \mathrm{~mm}$ (fork length) for the largescale data set and $208 \mathrm{~mm}$ (fork length) for the small-scale data set.

nested within ecotype. If we made inferences about all possible pairwise comparisons simultaneously, we employed a false discovery rate method to avoid the problem of type I errors in our analyses (Benjamini and Hochberg 1995; García 2003).

Finally, as a measure of the predictive power of our morphological measurements in distinguishing our hypothesized ecotypes, we used a linear combination of external features or internal organ sizes in discriminant function analyses to determine if we could reliably predict ecotype membership of a population based on average population scores.

\section{Results}

\section{Swimming and feeding morphology}

Our analysis of size-adjusted morphology indicated that there were significant differences in rainbow trout morphology both among populations within ecotypes and among ecotypes. When all size-adjusted external measurements were combined in a nested MANOVA, significant differences in morphology were found among rainbow trout ecotypes (Wilks' $\lambda=0.00075, F_{[77,103]}=3.12, P<0.0001$ ) and among populations nested within ecotypes (Wilks' $\lambda=$ $\left.0.022, F_{[286,15579]}=24.99, P<0.0001\right)$. In addition to the overall measure of morphological differentiation, 10 of 11 morphological features showed significant levels of differentiation among ecotypes based on univariate nested ANOVA, and all 11 characteristics had a significant, additional com- ponent of variation accounted for by the effect of population nested within ecotype (Table 2). On average, among-ecotype effects accounted for $28.4 \%$ of the variation in morphological traits (range $=11.6 \%-52.9 \%$ ), whereas among-population within-ecotype effects accounted for $25.6 \%$ (range $=18.2 \%$ $80.0 \%$ ) (Table 2).

When we summarized morphological differences by PCA, some but not all ecotypic categories were separated from each other based on PC scores. Four principal axes with eigenvalues greater than 1 were extracted from the PCA summarizing relative differences in morphological features (Table $3 a$ ). Across ecotypes, the most distinct separation occurred along the first axis between the three stream and five lakes ecotypes (Fig. 3a). A nested ANOVA of PC scores from the first axis revealed that $34.9 \%$ of the variation was accounted for by among-ecotype differences $\left(F_{[7,26]}=8.07\right.$, $P<0.0001)$ and $31.3 \%$ of the variation was accounted for by among-population within-ecotype differences (LR = $379.8, P<0.0001)$. The suite of morphological features that loaded most strongly along the first axis indicated that stream and piscivorous populations had relatively large head and eye dimensions (Table $3 a$ ). Based on PC scores from the second axis, $40.9 \%$ of the variation was accounted for by among-ecotype differences $\left(F_{[7,26]}=15.94, P<0.0001\right)$ and $20.6 \%$ of the variation was accounted for by amongpopulation within-ecotype differences $(\mathrm{LR}=222.3, P<$ 0.0001 ). The second principal axis separated groups primarily based on fin length and gill raker length (Table $3 a$ ). The 
Table 3. Loading coefficients from a principal component analysis (PCA) for (a) 11 external characteristics (including gill raking length and spacing) and (b) from a second PCA for five internal organ characteristics of 34 rainbow trout (Oncorhynchus mykiss) populations.

\begin{tabular}{lcccc}
\hline Morphological variable & PC 1 & PC 2 & PC 3 & PC 4 \\
\hline (a) External characteristics & & & & \\
Caudal peduncle depth & 0.28 & 0.17 & 0.73 & -0.14 \\
Body depth & -0.058 & -0.045 & 0.92 & 0.10 \\
Pectoral fin length & 0.36 & 0.57 & 0.24 & -0.14 \\
Pelvic fin length & 0.28 & 0.52 & 0.37 & 0.023 \\
Head length & 0.87 & -0.0043 & 0.046 & 0.101 \\
Premaxilla length & 0.88 & 0.038 & -0.071 & 0.09 \\
Mouth width & 0.81 & 0.046 & 0.066 & 0.081 \\
Head width & 0.74 & -0.089 & 0.19 & -0.097 \\
Eye diameter & 0.49 & 0.51 & -0.31 & -0.19 \\
Gill raker length & -0.16 & 0.86 & 0.0036 & 0.20 \\
Gill raker spacing & 0.09 & 0.058 & -0.011 & 0.97 \\
Eigenvalue & 4.67 & 1.49 & 1.12 & 1.025 \\
Proportion of total & 0.42 & 0.14 & 0.102 & 0.093 \\
(b) Internal organs & & & & \\
Stomach mass & 0.57 & 0.56 & -0.46 & -0.38 \\
Pyloric caeca mass & 0.83 & -0.27 & 0.12 & 0.17 \\
Intestine mass & 0.79 & -0.16 & -0.36 & 0.35 \\
Liver mass & 0.73 & -0.15 & 0.52 & -0.35 \\
Heart mass & 0.16 & 0.87 & 0.36 & -0.3 \\
Eigenvalue & 2.21 & 1.18 & 0.76 & 0.51 \\
Proportion of total & 0.44 & 0.24 & 0.15 & 0.10 \\
\hline
\end{tabular}

Note: Eigenvalues from each PC are listed below the column of coefficients.

third axis loaded most strongly on caudal peduncle and body depth (Table $3 a$ ). Based on PC scores from the third axis, $34.1 \%$ of the variation was accounted for by among-ecotype differences $\left(F_{[7,26]}=6.59, P=0.0002\right)$ and $33.8 \%$ of the variation was accounted for by among-population withinecotype differences $(\mathrm{LR}=379.0, P<0.0001)$. The fourth axis loaded most strongly on gill raker spacing (Table $3 a$ ); $18.6 \%$ of the variation was accounted for by ecotypic differences $\left(F_{[7,26]}=1.34, P=0.27\right)$, whereas $75.3 \%$ of the variation was accounted for by among-population within-ecotype differences $(\mathrm{LR}=1766.3, P<0.0001)$

When all eight ecotypes were compared against each other along the first principal axis, two separate groups comprising all stream ecotypes as well as piscivorous and mixed 1 ecotypes were distinguished from all remaining lake ecotypes (Fig. 3a). Based on scores from the second axis, anadromous and headwater ecotypes were distinguished from all other ecotypes (Fig. 3a). Although stream ecotypes were not significantly separated from each other based on scores from the first principal axis $\left(F_{[2,12]}=0.27, P=0.77\right)$, when all stream ecotypes were compared against all lake ecotypes, stream ecotypes had higher scores than lake ecotypes $\left(F_{[1,32]}=46.99, P<0.0001\right)($ Fig. $3 a)$. In contrast, piscivorous lake ecotypes could not be distinguished from stream populations $\left(F_{[1,26]}=1.32, P=0.26\right)$ but did have higher scores than other lake ecotypes $\left(F_{[1,26]}=6.89, P=0.014\right)$ (Fig. 3a). Along the second principal axis, stream ecotypes had significantly higher scores than lake ecotypes $\left(F_{[1,32]}=\right.$ 61.80, $P<0.0001)$ and were highest for anadromous and headwater populations in comparison with all other ecotypes
(Fig. 3a). The third axis, primarily distinguishing caudal peduncle and body depth, could not differentiate stream and lake ecotypes $\left(F_{[1,32]}=0.35, P=0.56\right)$; however, headwater populations had higher scores than all other ecotypes except large river populations (Fig. 3b). Given that there was no additional component of variation accounted for by ecotypic differences along the fourth axis, we did not consider it further.

\section{Internal organ size}

Our analysis of internal organs indicated that there were significant differences in rainbow trout organ size both among populations within ecotypes and among ecotypes. When the mass of all size-adjusted organs were combined in a nested MANOVA, significant differences in organ size were found among rainbow trout ecotypes (Wilks' $\lambda=$ $\left.0.081, F_{[35,95]}=2.22, P=0.0012\right)$ and among populations nested within ecotypes (Wilks' $\lambda=0.16, F_{[130,7474]}=26.42$, $P<0.0001)$. Three of five features showed significant levels of differentiation among ecotypes based on univariate nested ANOVA (Table 4). All five characteristics had a significant additional component of variation accounted for by the effect of population nested within ecotype (Table 4). On average, among-ecotype effects accounted for $22.8 \%$ of the variation in organ sizes (range $=9.1 \%-42.6 \%$ ), whereas among-population within-ecotype effects accounted for $40.0 \%$ of the variation (range $=17.7 \%-57.8 \%$ ) (Table 4 ).

Two principal axes with eigenvalues greater than 1 were extracted from the PCA summarizing relative differences in organ size (Table $3 b$ ). All internal organs except heart mass 
Fig. 3. Mean principal component scores $( \pm 1 \mathrm{SE})$ based on 11 morphological characteristics for eight ecotypic categories of 34 rainbow trout (Oncorhynchus mykiss) populations comparing (a) axis 1 versus axis 2 and (b) axis 1 versus axis 3. (c) Mean principal component scores $( \pm 1 \mathrm{SE}$ ) based on five internal organ sizes for eight ecotypic categories of 34 rainbow trout populations comparing axis 1 versus axis 2 . Note that Fig. $3 c$ represents scores from a completely separate principal component analysis than in Fig. $3 a$ or Fig. $3 b$. Means that are not significantly different from each other on either axis (pairwise adjusted $P>0.05)$ share both a common vertical and a common horizontal line within the plot area.

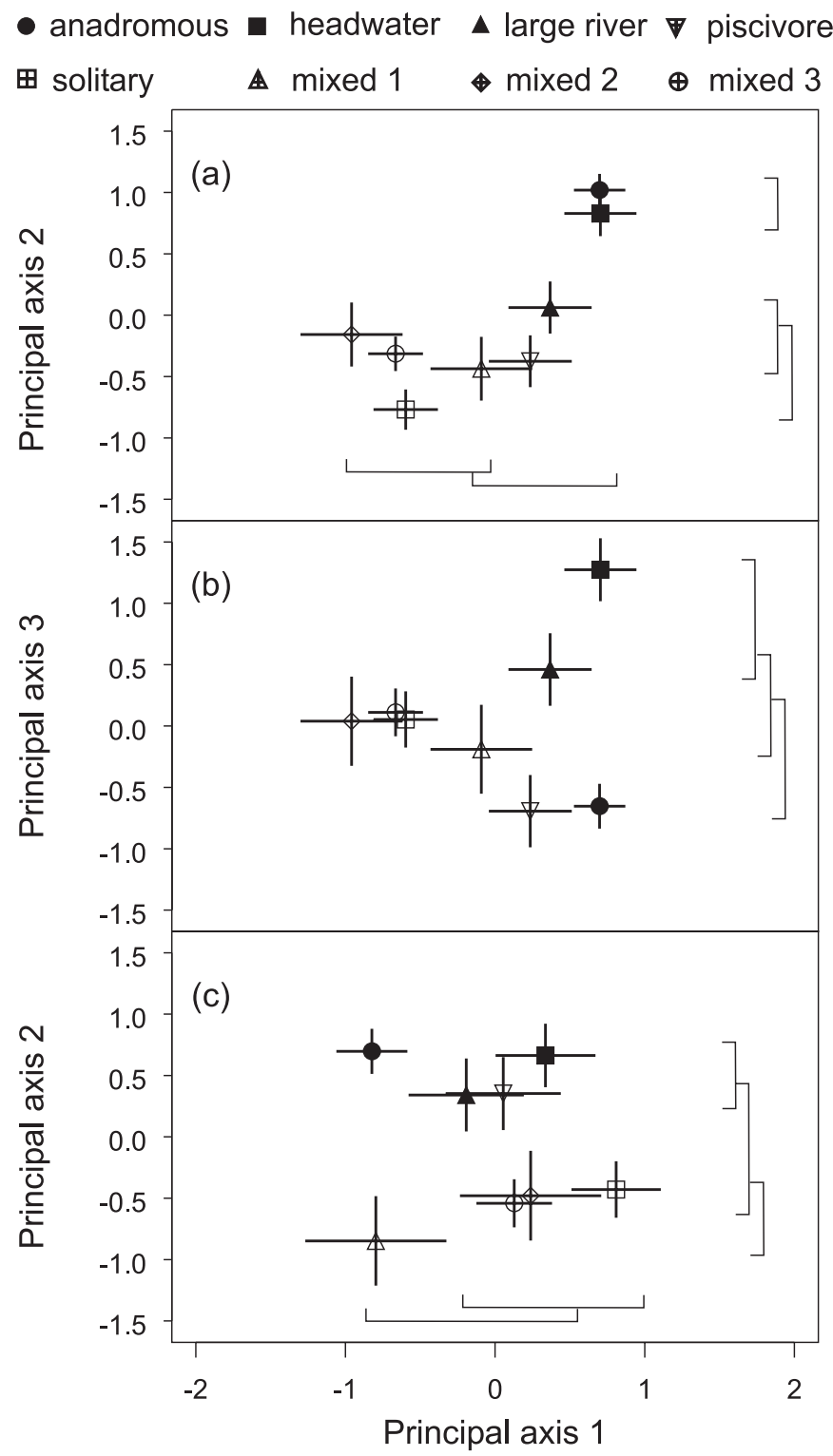

loaded strongly along the first axis, whereas heart mass and stomach mass loaded strongly along the second axis (Table $3 b$ ). A nested ANOVA of PC scores along the first axis found that $29.7 \%$ of the variation was accounted for by among-ecotype differences $\left(F_{[7,26]}=3.42, P=0.010\right)$ and $54.9 \%$ of the variation was accounted for by amongpopulation within-ecotype differences $(\mathrm{LR}=932.0, P<$ 0.0001). When all eight ecotypes were compared along the first axis, only solitary populations could be distinguished from anadromous, large river, and mixed 1 ecotypes (Fig. 3c). Despite the overlap in scores across the first axis, when all lake ecotypes were compared against all stream ecotypes, lake ecotypes (mean PC score $=0.21$ ) had higher scores than stream ecotypes (mean PC score $=-0.39$; $\left.F_{[1,26]}=4.96, P=0.033\right)$. Based on PC scores from the second axis, $23.1 \%$ of the variation was accounted for by among-ecotype differences $\left(F_{[7,26]}=5.96, P=0.0003\right)$ and $33.8 \%$ of the variation was accounted for by amongpopulation within-ecotype differences $(\mathrm{LR}=374.8, P<$ 0.0001). When compared along the second principal axis, stream and piscivorous ecotypes were most similar but were only significantly different from mixed 1 ecotypes.

\section{Discriminant analyses}

Using the 11 size-adjusted external features, three significant canonical axes were extracted from our discriminant analysis, resulting in correct classification of the putative ecotypes in 32 of 34 populations (94\%) and accounting for $91.1 \%$ of the morphological variation between ecotypes (Table $5 a$ ). The only misclassifications occurred between two lake populations, when one mixed 3 population was misclassified as a piscivorous population and one solitary population was misclassified as a mixed 2 population. Stream-dwelling populations were most strongly differentiated from other ecotypes by the first canonical axis, which loaded positively on nine of 11 characteristics (Table $5 a$; Fig. 4a). Piscivorous populations were primarily differentiated along the third canonical axis based on relatively large head features such as premaxilla length, head length, and mouth width (Table 5a; Fig. $4 b$ ).

When we performed a discriminant analysis using internal organ sizes to differentiate rainbow trout ecotypes, we were less successful at predicting group membership. Only the first axis accounted for a significant proportion of the variation in morphology, successfully classifying ecotype membership in 27 of 34 cases or a $79.4 \%$ success rate (Table $5 b$ ). Discriminant analyses of internal organ features were best at separating stream versus lake ecotypes, but within each of these two general categories, the groups were often intermixed (Fig. 4c).

\section{Small-scale variation in morphology}

On a smaller spatial scale, we found that most lakes or streams sampled within a watershed tended to have a similar species composition. Of the 27 interconnected lakes or streams sampled, 21 lakes had a rainbow trout population sympatric with at least one species of benthivorous and planktivorous fish (a mixed 3 ecotype) and were usually composed of the same species (Fig. 1b; Appendix A). Two lakes had solitary populations of rainbow trout and two streams had headwater populations isolated above an upstream migration barrier. Only the largest river in one subwatershed supported a large river population of rainbow trout. As with the large-scale data set, a significant component of variation in morphological traits was accounted for by populations nested within ecotypes (MANOVA, Wilks' $\left.\lambda=0.021, F_{[231,10999]}=21.01, P<0.0001\right)$ and a marginal amount among ecotypes (MANOVA, Wilks' $\lambda=0.027$, $\left.F_{[44,44.04]}=1.57, P=0.070\right)$. In addition to the overall mea- 
Table 4. Results from univariate nested ANOVA for five internal organ characteristics of rainbow trout (Oncorhynchus mykiss) comparing the variation accounted for among populations nested within ecotypes or among ecotypes.

\begin{tabular}{|c|c|c|c|c|c|}
\hline \multirow[b]{2}{*}{ Morphological trait } & \multirow[b]{2}{*}{ Variance component } & \multicolumn{2}{|c|}{ Large-scale variation } & \multicolumn{2}{|c|}{ Small-scale variation } \\
\hline & & $\begin{array}{l}\% \text { of total } \\
\text { variation }\end{array}$ & $P$ & $\begin{array}{l}\% \text { of total } \\
\text { variation }\end{array}$ & $P$ \\
\hline \multirow[t]{2}{*}{ Stomach mass } & Among populations within ecotypes & 57.8 & 0.0002 & 51.4 & 0.0007 \\
\hline & Among ecotypes & 27.9 & 0.034 & 23.5 & 0.030 \\
\hline \multirow[t]{2}{*}{ Pyloric caeca mass } & Among populations within ecotypes & 49.9 & 0.0002 & 31.6 & 0.0010 \\
\hline & Among ecotypes & 42.6 & 0.0001 & 9.4 & 0.14 \\
\hline \multirow[t]{2}{*}{ Intestine mass } & Among populations within ecotypes & 41.2 & 0.0003 & 50.5 & 0.0007 \\
\hline & Among ecotypes & 22.5 & 0.018 & 4.3 & 0.74 \\
\hline \multirow[t]{2}{*}{ Liver mass } & Among populations within ecotypes & 33.5 & 0.0003 & 25.2 & 0.0013 \\
\hline & Among ecotypes & 12.1 & 0.11 & 8.2 & 0.13 \\
\hline \multirow[t]{2}{*}{ Heart mass } & Among populations within ecotypes & 17.7 & 0.0011 & 29.9 & 0.0010 \\
\hline & Among ecotypes & 9.1 & 0.097 & 8.8 & 0.16 \\
\hline
\end{tabular}

Note: Large-scale variation refers to 34 populations sampled across British Columbia, and small-scale variation refers to 27 populations sampled within a single watershed. All traits were adjusted to a common body mass of $143 \mathrm{~g}$ for the large-scale data set and $134 \mathrm{~g}$ for the small-scale data set.

Table 5. Loading coefficients from a discriminant analysis for (a) 11 external characteristics (including gill raking length and spacing) and (b) from a second discriminant analysis for five internal organ characteristics of 34 rainbow trout (Oncorhynchus mykiss) populations from across British Columbia.

\begin{tabular}{lccc}
\hline Morphological variable & Canonical axis 1 & Canonical axis 2 & Canonical axis 3 \\
\hline (a) External characteristics & & & \\
Caudal peduncle depth & 0.53 & 0.64 & 0.11 \\
Body depth & -0.17 & 0.54 & 0.14 \\
Pectoral fin length & 0.81 & 0.20 & 0.31 \\
Pelvic fin length & 0.61 & 0.43 & 0.45 \\
Head length & 0.51 & -0.04 & 0.55 \\
Premaxilla length & 0.69 & -0.103 & 0.58 \\
Mouth width & 0.78 & 0.093 & 0.36 \\
Head width & 0.66 & 0.14 & -0.15 \\
Eye diameter & 0.90 & -0.201 & 0.0019 \\
Gill raker length & 0.69 & -0.23 & -0.26 \\
Gill raker spacing & -0.33 & 0.042 & 0.202 \\
Eigenvalue & 14.71 & 3.66 & 2.62 \\
Proportion of total & 0.64 & 0.16 & 0.11 \\
(b) Internal organs & & & \\
Stomach mass & -0.34 & 0.74 & 0.51 \\
Pyloric caeca mass & 0.82 & 0.48 & 0.26 \\
Intestine mass & 0.64 & 0.34 & 0.58 \\
Liver mass & 0.54 & 0.304 & 0.54 \\
Heart mass & -0.56 & 0.302 & 0.37 \\
Eigenvalue & 3.78 & 0.92 & 0.27 \\
Proportion of total & 0.75 & 0.18 & 0.054 \\
\hline
\end{tabular}

sure of morphological differentiation, six of 11 morphological features showed significant levels of differentiation among ecotypes based on univariate nested ANOVA, and all 11 characteristics had a significant, additional component of variation accounted for by the effect of population nested within ecotype. On average, among-ecotype effects accounted for $20.2 \%$ of the variation in morphological traits (range $=0.6 \%-42.4 \%$ ), whereas among-population withinecotype effects accounted for $37.4 \%$ (range $=24.3 \%-61.7 \%$ ) (Table 2).
In comparison with the large-scale data set, we again found similar morphological differences by ecotypic category when the traits were summarized by PCA groupings. Stream populations had significantly larger PC scores based on the first $\mathrm{PC}$ axis $\left(F_{[1,24]}=30.00, P<0.0001\right)$ (Fig. 5a), which loaded most strongly on fin length and head dimensions (Table 6). A nested ANOVA of PC scores from the first axis revealed that $46.3 \%$ of the variation was accounted for by among-ecotype differences $\left(F_{[4,21]}=8.54, P=0.0003\right)$ and $48.7 \%$ of the variation was accounted for by differences 
Fig. 4. Canonical scores based on 11 morphological features from a discriminant analysis of 34 rainbow trout (Oncorhynchus mykiss) populations for $(a)$ axis 1 versus axis 2 and $(b)$ axis 1 versus axis 3 across eight ecotypic categories. (c) Canonical scores based on five internal organ size characteristics from a discriminant analysis of 34 rainbow trout populations for axis 1 versus axis 2 across eight ecotypic categories. Note that Fig. $4 c$ represents scores from a completely separate discriminant analysis than in Fig. $4 a$ or Fig. $4 b$.
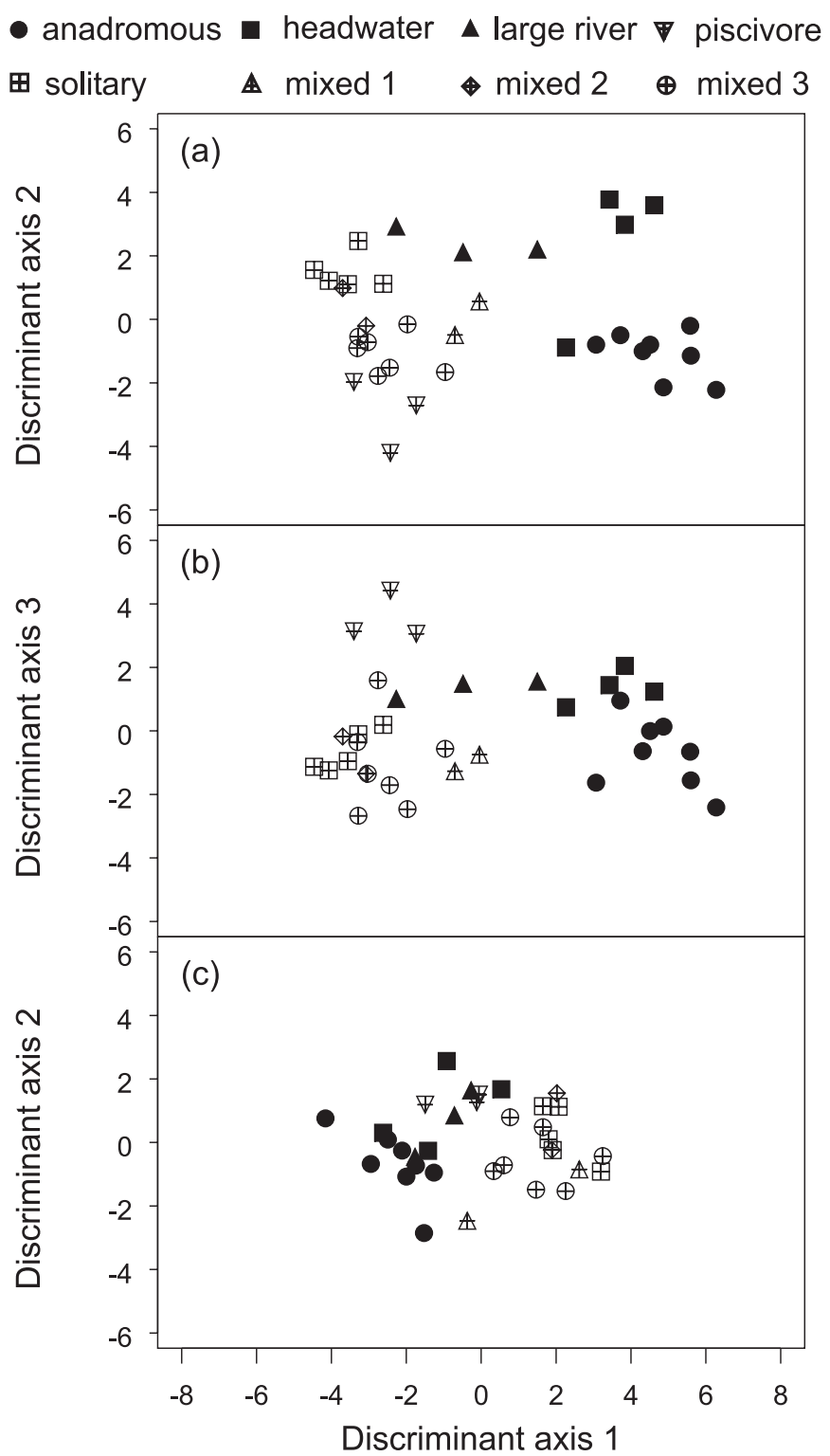

among populations nested within ecotypes (LR $=449.6, P<$ $0.0001)$. Based on PC scores from the second axis, $9.9 \%$ of the variation was accounted for by among-ecotype differences $\left(F_{[4,21]}=1.81, P=0.16\right)$ and $47.8 \%$ of the variation was accounted for by differences among populations nested within ecotypes $(\mathrm{LR}=565.4, P<0.0001)$. The second principal axis provided weak separation of groups primarily based on caudal peduncle and body depth (Table 6a). The third axis loaded most strongly on gill raker spacing. Based on PC scores from the third axis, $9.1 \%$ of the variation was accounted for by among-ecotype differences $\left(F_{[4,21]}=1.72\right.$,
Fig. 5. Mean principal component scores $( \pm 1 \mathrm{SE})$ based on 11 morphological characteristics for eight ecotypic categories of 27 rainbow trout (Oncorhynchus mykiss) populations comparing (a) axis 1 versus axis 2 and (b) axis 1 versus axis 3. (c) Mean principal component scores $( \pm 1 \mathrm{SE})$ based on five internal organ sizes for eight ecotypic categories of 27 rainbow trout populations comparing axis 1 versus axis 2 . Note that Fig. $5 c$ represents scores from a completely separate principal component analysis than in Fig. $5 a$ or Fig. $5 b$. Means that are not significantly different from each other on either axis (pairwise adjusted $P>0.05$ ) share both a common vertical and a common horizontal line within the plot area except in Fig. $5 c$ for headwater versus mixed 3 populations, which were different based on the second principal axis.

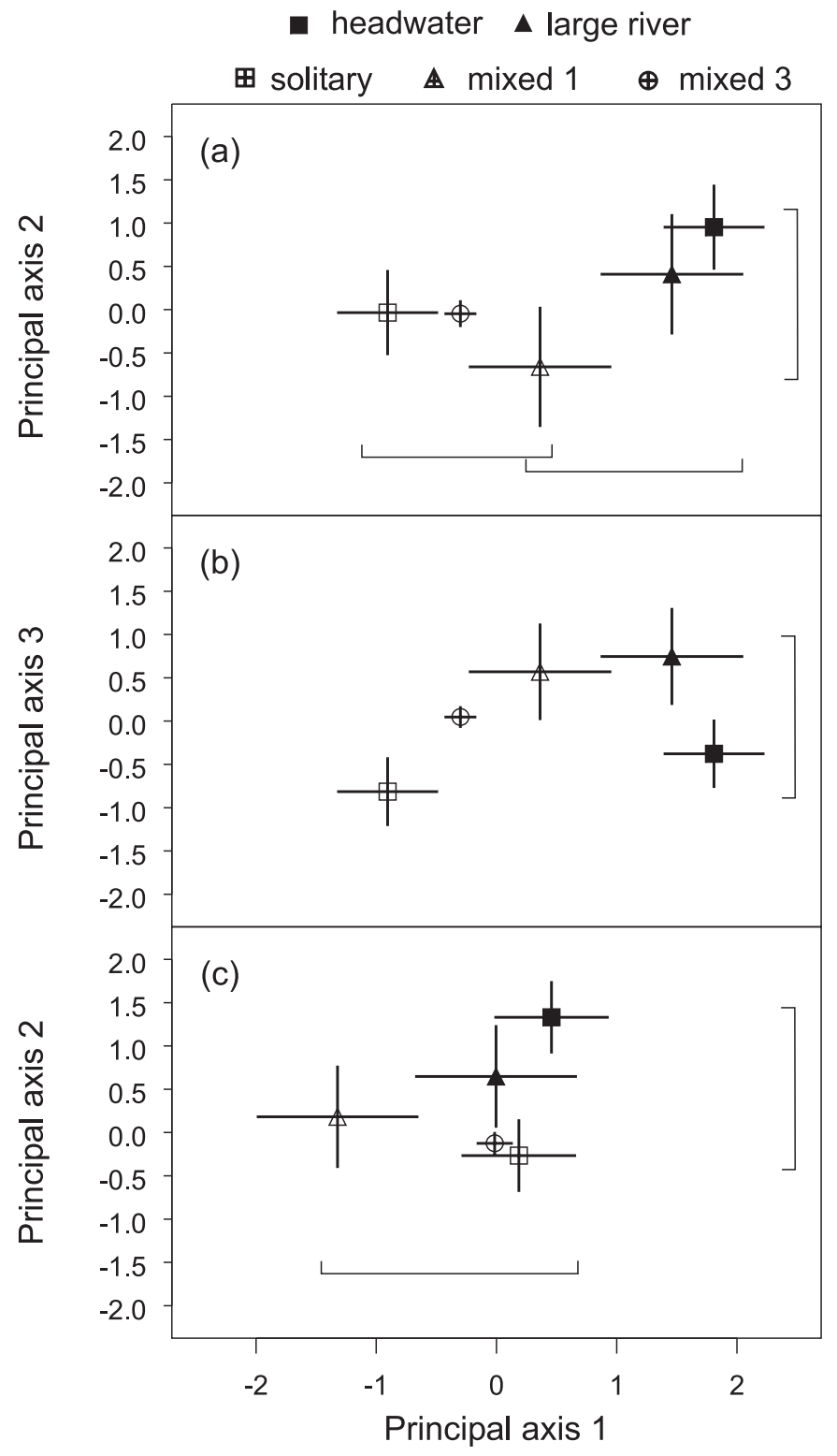

$P=0.18$ ), whereas $31.2 \%$ of the variation was accounted for by among-population within-ecotype differences $(\mathrm{LR}=315.1$, $P<0.0001)$.

Our analysis of internal organs on the small-scale data set indicated that there were significant differences in rainbow 
Table 6. Loading coefficients from a principal component analysis (PCA) for (a) 11 external characteristics and $(b)$ from a second PCA for five internal organ characteristics of 27 rainbow trout (Oncorhynchus mykiss) populations from within a single watershed.

\begin{tabular}{lccc}
\hline Morphological variable & PC 1 & PC 2 & PC 3 \\
\hline (a) External characteristics & & & \\
Caudal peduncle depth & 0.1006 & 0.83 & -0.0059 \\
Body depth & -0.053 & 0.85 & -0.086 \\
Pectoral fin length & 0.80 & -0.073 & -0.23 \\
Pelvic fin length & 0.80 & -0.03 & -0.23 \\
Head length & 0.85 & 0.12 & 0.081 \\
Premaxilla length & 0.80 & 0.088 & 0.074 \\
Mouth width & 0.71 & 0.05 & 0.12 \\
Head width & 0.63 & 0.38 & 0.11 \\
Eye diameter & 0.68 & -0.13 & 0.16 \\
Gill raker length & -0.014 & 0.076 & 0.25 \\
Gill raker spacing & 0.028 & -0.049 & 0.93 \\
Eigenvalue & 4.45 & 1.57 & 1.12 \\
Proportion of total & 0.41 & 0.14 & 0.10 \\
(b) Internal organs & & & \\
Stomach mass & 0.7 & -0.047 & -0.61 \\
Pyloric caeca mass & 0.53 & -0.39 & 0.67 \\
Intestine mass & 0.83 & -0.28 & 0.082 \\
Liver mass & 0.42 & 0.62 & 0.34 \\
Heart mass & 0.28 & 0.77 & -0.00068 \\
Eigenvalue & 1.7 & 1.21 & 0.94 \\
Proportion of total & 0.34 & 0.24 & 0.19 \\
\hline
\end{tabular}

trout organ size among populations nested within ecotypes but not among ecotypes. When all size-adjusted organs were combined in a nested MANOVA, there were no significant differences in organ size among the five rainbow trout ecotypes (Wilks' $\lambda=0.22, F_{[20,57.3]}=1.64, P=0.075$ ). One of the five features exhibited significant levels of differentiation among ecotypes based on univariate nested ANOVAs (Table 4). A significant proportion of morphological variation was, however, accounted for by differences among populations nested within ecotypes (Wilks' $\lambda=0.13$, $F_{[105,5720.5]}=28.31, P<0.0001$, and all five characteristics had a significant additional component of variation accounted for by the effect of population nested within ecotype (Table 4). On average, among-ecotype effects accounted for $10.8 \%$ of the variation in morphological traits (range = $4.3 \%-51.4 \%$ ), whereas among-population within-ecotype effects accounted for $31.3 \%$ of the variation (range $=$ $25.2 \%-50.4 \%$ ) (Table 4).

Two principal axes with eigenvalues greater than 1 were extracted from the PCA summarizing relative differences in organ size (Table 6b). All internal organs loaded strongly along the first axis, and heart and liver size loaded strongly along the second axis (Table 6b). Based on a nested ANOVA of PC scores from the first axis, $9.2 \%$ of the variation was accounted for by among-ecotype effects $\left(F_{[4,21]}=1.24, P=\right.$ 0.33 ) and $45.5 \%$ of the variation was accounted for by among-population within-ecotype effects $(\mathrm{LR}=575.0, P<$ $0.0001)$. When compared along the second PC axis, $17.3 \%$ of the variation was accounted for by among-ecotype effects
$\left(F_{[4,21]}=3.18, P=0.035\right)$ and $38.5 \%$ of the variation by among-population within-ecotype effects ( $\mathrm{LR}=442.9, P<$ $0.0001)$. The relatively low proportion of variation accounted for by ecotypic differences in organ size was reflected in the overlap of PC scores when compared by ecotype (Fig. 5c). We could not detect any significant difference among ecotypes along the first axis $\left(F_{[4,22]}=1.24, P=0.33\right)$. There were, however, differences across the second axis $\left(F_{[4,22]}=\right.$ 3.18, $P=0.035)$ : stream ecotypes had higher scores than lake ecotypes $\left(F_{[1,24]}=12.32, P=0.0018\right)$ (Fig. 5c). Based on pairwise comparisons, only headwater ecotypes could be distinguished from mixed 3 ecotypes along the second principal axis (Fig. 5c).

We also applied the discriminant function from the largescale data set to classify the small-scale data set and to test its applicability to an unrelated sample based on external characteristics. Despite similar patterns in morphologybased PC scores and the high predictive ability of the largescale data set in correctly classifying ecotypic category, the success was not as high when the large-scale discriminant function was applied to the interconnected system of streams and lakes. Although all stream populations were correctly classified as stream ecotypes and 22 of 24 lake populations were correctly classified as lake ecotypes, only 19 of 27 populations in the small-scale data set were correctly classified by the large-scale discriminant function. Four lake populations were assigned to an incorrect lake category and two were assigned as stream ecotypes. In addition, one headwater stream population was assigned as an anadromous ecotype and the large river population was assigned as a headwater ecotype.

\section{Discussion}

Our data indicate that a significant proportion of morphological variation among rainbow trout populations is associated with our hypothesized ecotypic categories, with the largest differences occurring between stream- and lakedwelling populations. Several observations suggest that the differences in body and fin morphology between stream and lake populations are adaptive responses to differences in water velocity. Salmonids often use their pectoral fins as hydrofoils to minimize energy expenditure in streams (Arnold et al. 1991). A relatively large surface area is more effective at generating negative lift than a small one (Webb 1975, 1978). This may explain why we observed that stream populations tended to have larger paired fins when compared with lakedwelling populations. A number of past studies have also found that salmonid morphology is influenced by water velocity, but the morphological response to higher velocity can vary both within and between species. For example, Riddell and Leggett (1981) found that juvenile Atlantic salmon (Salmo salar) from a higher gradient stream differed than those from a lower gradient stream primarily in pectoral fin length and possibly as a result of higher water velocities in the high-gradient stream. Among individuals within populations, both McLaughlin and Grant (1994) and Imre et al. (2002) found that brook trout from high water velocities had larger caudal fins than those from lower water velocities, but they found opposing differences in caudal peduncle height. Similarly, Pakkasmaa and Piironen 2001 found that Atlantic 
salmon had deeper bodies under increased flow, but brown trout (Salmo trutta) exhibited no difference. Although past studies have consistently found that water velocity influences salmonid morphology, the variability in morphological responses suggests that other factors also play a role.

Within stream ecotypes, anadromous populations exhibited the most distinctive morphology. Anadromous populations tended to have the largest mouth and head size as well as the largest eye size among all rainbow trout populations. This distinctive morphology is associated with an ontogenetic habitat shift from a freshwater to a marine environment that is absent in both resident stream ecotypes. In addition to facing a prolonged period in a stream environment as juveniles, anadromous fish must undertake long migrations and cope with a switch to feeding on fish in an ocean environment (Pearcy 1992). Since our samples include fish taken prior to ocean migration (i.e., in an environment similar to that of resident fish), anadromous rainbow trout morphology may, therefore, reflect adaptation to this ontogenetic switch between freshwater and marine environments.

Rainbow trout from populations that were classified as piscivorous had some features that were larger in comparison with all other lake populations. As expected for a predator that feeds on relatively large prey, our prediction that piscivorous rainbow trout would have the largest mouth features among all lake populations was supported by relatively large premaxilla and head lengths. As in other taxa of fishes, species that tend to have a large proportion of fish in their diet also tend to have large mouths relative to their body size than nonpiscivorous species or populations (Snorrason et al. 1994; Wainwright and Richard 1995). In addition to mouth morphology, piscivorous rainbow trout appear to have a narrow caudal peduncle relative to other lake ecotypes. Although we know of no other intraspecific study with a similar result, others have noted that across fish taxa, open-water predators such as the billfishes (Xiphiidae) and tunas (Scombridae) do tend to have relatively narrow caudal peduncles, a trend that has been argued to stem from selection for the most efficient configuration for an open-water, cruising predator (Lindsey 1978; Webb 1978). The samples from the piscivorous populations that we studied also included juveniles collected from stream and littoral lake habitats prior to the initiation of open-water piscivory at about age 2 and $20 \mathrm{~cm}$ in length (Andrusak and Parkinson 1984). This suggests that the morphological differences that we found are not entirely induced by the unusual diet and habitat of adult piscivores.

The presence of competing species is a factor that is thought to be an important force in shaping the phenotype of a species. In fishes, numerous examples exist of dramatic trophic and morphological diversification among species that depends on the composition of competitors present in lakes (Robinson and Wilson 1994). We chose to compare lakes where rainbow trout had no fish competitors present, with lakes where only a benthos competitor, a plankton-benthos competitor, or both types were present. In salmonids, benthic catostomid species that feed on larval insects at the bottom of lakes are important competitors for this potential prey source for coexisting salmonids (Magnan 1988). In rainbow trout, cyprinid fishes such as redside shiners (Richardsonius balteatus) or lake chub (Couesius plumbeus) may be important plankton competitors (Johannes and Larkin 1961; Magnan 1988). We predicted that the presence of such species might be responsible for a displacement of morphological characters in rainbow trout because of this potential competitive influence. Our data indicate that rainbow trout from solitary populations tend to have some of the smallest head features of all of the populations that we sampled but were not significantly different from the populations that were sympatric with a minnow species. As Magnan (1988) and Bourke et al. (1999) suggested, small-bodied cyprinid or minnow species may actually impose very little competitive influence on co-occurring salmonids. The similarities in morphology among solitary rainbow trout populations and those that were sympatric only with a minnow species are consistent with this observation.

Despite the importance of gill raker length and spacing in exploiting zooplankton prey in some species of freshwater fish (e.g., Lavin and McPhail 1986; Sanderson et al. 2001), we could not detect any pattern of diversification in gill rakers among the lake populations of rainbow trout that we sampled. Intraspecific divergence in gill raker morphology is common in fish but was noticeably absent among the populations that we studied. Most previous observations are in sympatric benthic-pelagic species pairs (Taylor 1999) and appear to be the result of character displacement driven by competition (Pritchard and Schluter 2001). Sympatric populations of closely related species show similar character displacement (e.g., McDowell 1998). The absence of divergence that we observed among allopatric populations of rainbow trout that were paired with benthic and pelagic competitors suggests that distantly related species do not produce the same level of character displacement as closely related species or sympatric populations of the same species.

Unlike external features, internal organ sizes did not provide as strong discriminating abilities. For instance, despite living in a flowing-water environment, there appeared to be only a small difference between stream-dwelling populations and lake populations in terms of heart size. Given that ventricle size is correlated with cardiac output and aerobic capacity (Farrell et al. 1990), we expected that stream populations, which must swim continually to maintain position, would have a larger heart size than lake populations. Similarly, we also expected intestine size in piscivorous populations to be relatively small because piscivorous fishes tend to have a shorter gut length than omnivores or herbivores (Kramer and Bryant 1995). Instead, we found little difference among ecotypes, which suggests that gut size has not been influenced by differences across ecotypes.

Within ecotypes, morphological differences among individual fish from the same population were smaller than the differences among individuals from different populations. In contrast with our large-scale comparison, these differences cannot be replicated in different locations and there are no a priori predictions for the type of differences that may be expected. Nevertheless, these observations are consistent with the presence of adaptive radiation among populations within an ecotype. Previous studies of anadromous trout have documented differences among populations in life history characteristics, such as percentage of repeat spawning, time of 
return to fresh water, and adult body size (Withler 1966) along with the heritability of some of these differences (Smith 1969; Tipping 1991). The other ecotypes in this study have not been examined as extensively as anadromous trout, but we expect that the variation among the ecotypes that we observed is only a fraction of the overall variation among populations within this species.

A key goal of our work is to develop a practical method of documenting adaptive genetic variation to identify rare and endangered ecotypes for conservation purposes. Phenotypic variation among populations, such as that documented in this study, probably results from a combination of genetic divergence and phenotypic plasticity (Robinson and Parsons 2002). We did not estimate the heritability of each trait in each population, and therefore, we cannot differentiate genetic variation from phenotypic plasticity. However, if the association between environment and phenotype is partially the result of genetic adaptation to local environmental conditions, then the environment can be used as a surrogate for genetic variation. The success of this approach depends on the strength of this relationship between genetic and environmental variation.

Several lines of evidence suggest that the association between morphological and environmental variation that we observed in rainbow trout is partially the result of natural selection for genetically based traits that have adaptive significance. Clearly, some variation in morphology is the result of phenotypic plasticity (Pakkasmaa and Piironen 2001; Imre et al. 2002), but a variety of studies have shown that differences in morphology between salmonid populations have significant, measurable heritabilities (Riddell et al. 1981; Skúlason et al. 1989; Proulx and Magnan 2004). These differences occur in consistent, predictable directions (larger fins at higher velocity, larger mouths in piscivores), which suggests that some are likely under selective pressure in natural environments (Taylor 1991). More directly, we have obtained evidence of a genetic basis of the phenotypic difference that we have documented in this study for a subset of six populations representing solitary lake, mixedspecies lake, piscivorous lake, headwater stream, large river, and anadromous ecotypes (E.R. Keeley, E.A. Parkinson, and E.B. Taylor, unpublished data). In this companion study, between $18 \%$ and $79 \%$ of the total phenotypic variation (depending on the trait) was attributable to differences among ecotypes raised under controlled environmental conditions (E.R. Keeley, E.A. Parkinson, and E.B. Taylor, unpublished data). Although we could not partition maternal effects from the among-population component of the variation, the persistence of ecotypic morphological differences under controlled environmental conditions supports the idea that much of the phenotypic variation that we have documented is under genetic control and can respond to different, environment-specific selection regimes. In our data set from the native populations, juveniles from at least two ecotypes (anadromous, piscivore) can be differentiated from other ecotypes prior to entering their distinctive environments. Distinguishing what proportion of the variation in morphology is a response to varying environmental conditions or represents relatively fixed differences as a result of selection remains to be tested experimentally in rainbow trout ecotypes.

\section{Conservation implications of ecotypic variation}

Intraspecific diversity has been recognized as an important component of biodiversity (Waples 1995; Waples et al. 2002) and is particularly important in areas such as the freshwater habitats of northwestern North America, which have a relatively depauperate fish fauna. British Columbia covers an area of approximately $950000 \mathrm{~km}^{2}$ but has fewer than 70 officially described species of native freshwater fishes. Taxonomic units in conservation plans clearly must include more than the species level of classification to capture adaptive divergence among populations within species (Hard 1995; Allendorf and Waples 1996; Crandall et al. 2000).

Diversity among rainbow trout populations has been an issue for biologists attempting to create lists of regional fauna for some time. Early efforts to describe rainbow trout diversity from British Columbia resulted in three described species: anadromous (steelhead) trout (Salmo gairdneri), Kamloops trout (Salmo kamloops), and mountain Kamloops trout (Salmo kamloops whitehousei), as well as earlier speculation on up to 16 different types of rainbow trout (Jordan et al. 1930; Dymond 1932; Mottley 1936a). Although early researchers recognized that different forms occupied different ecological roles, all forms of rainbow trout were eventually placed under a single species ( $S$. gairdneri and later O. mykiss; Stearley 1993) because some of the meristic characteristics used to define a species were found to be largely environmentally induced (Mottley 1936a, 1936b). As is the case for neutral molecular diversity, some meristic characters may be used to define phylogenetic groups but may not represent ecological characteristics that are important for persistence in particular environments. Because our analysis has shown that significant morphological variation, under at least partial genetic control, is consistently associated with habitat characteristics that are relatively easy to quantify on a large scale, it may provide a practical methodology for conservation planners to encapsulate differences among populations of polytypic species that are of high conservation concern. In the face of ever-expanding threats to native populations by human activities, our method provides a precautionary means of assessing the frequency of relatively rare forms of rainbow trout before any damaging activities occur. This is an important consideration in conservation planning where priorities for protection must be assessed among thousands of populations that cannot be examined individually. For example, we were able to morphologically distinguish populations of large piscivorous rainbow trout from other populations. This ecotype is consistently found only in lakes greater than about 10000 ha in surface area that also support kokanee (Oncorhynchus nerka), which is the key prey species for piscivorous rainbow trout in these lakes. Importantly, fewer than 15 lakes in British Columbia fit this description and those easily accessible to humans have had stringent harvest regulations imposed because of heavy exploitation pressure.

Habitat-phenotype associations that we have documented in rainbow trout suggest a landscape ecological approach that can be used as an alternative proxy measure of adaptive variation, i.e., inferring phenotype divergence from habitat (Watters et al. 2003). This approach, in combination with phylogeographic diversity (e.g., Crandall et al. 2000; 
McCusker et al. 2000) and landscape genetics (how landscape may influence gene flow among populations; e.g., Manel et al. 2003), can form an important component of assessing conservation priorities. Our study represents a contribution towards justification, when necessary, of a means to balance the desire for detailed scientific documentation of the adaptive significance of phenotypic variation among populations with the pragmatic need for conservation planning and decisions that must often be made over short time frames.

\section{Acknowledgements}

We thank J. Scroggie, M. Phillotts, S. Fancy, P. Tamkee, J. Hagen, A. Jenkins, Q. Tuckett, D. Piatt, M. Porter, J. Schultz, and W. McCleese for help in the laboratory or field. G. Reid, J. Leggett, B. Hooton, D. Atagi, D. Cadden, J. Hammond, D. McPhail, and D. Schluter provided helpful comments on the study design and on location of study populations. We thank the staff of Tweedsmuir, Wells Gray, and Tatlatui Provincial Parks for assistance and permission to collect within park boundaries. Financial support was provided by grants from Forest Renewal British Columbia, by the Natural Sciences and Engineering Research Council of Canada, by The University of British Columbia, and by Idaho State University. J. Meka, I. Imre, three anonymous reviewers, and various members of the Native Fishes Research Group at The University of British Columbia provided additional helpful comments on an earlier version of this work.

\section{References}

Allendorf, F.W., and Waples, R.S. 1996. Conservation and genetics of salmonid fishes. In. Conservation genetics: case histories from nature. Edited by J.C. Avise and J.L. Homrick. Chapman and Hall, New York. pp. 238-280.

Andrusak, H., and Parkinson, E.A. 1984. Food habits of Gerrard stock rainbow trout in Kootenay Lake, British Columbia. Prov. B.C. Fish. Tech. Circ. No. 60.

Arnold, G.P., Webb, P.W., and Holford, B.H. 1991. The role of pectoral fins in station-holding of Atlantic salmon parr (Salmo salar). J. Exp. Biol. 156: 625-629.

Benjamini, Y., and Hochberg, Y. 1995. Controlling the false discovery rate: a practical and powerful approach to multiple testing. J. R. Stat. Soc. Ser. B (Methodol.), 57: 289-300.

Bergot, P., Blanc, J.M., and Escaffre, A.M. 1981. Relationship between number of pyloric caeca and growth in rainbow trout (Salmo gairdneri Richardson). Aquaculture, 22: 81-96.

Boily, P., and Magnan, P. 2002. Relationship between individual variation in morphological characters and swimming costs in brook charr (Salvelinus fontinalis) and yellow perch (Perca flavescens). J. Exp. Biol. 205: 1031-1036.

Bourke, P., Magnan, P., and Rodríguez, M.A. 1999. Phenotypic responses of lacustrine brook charr in relation to the intensity of interspecific competition. Evol. Ecol. 13: 19-31.

Crandall, K.A., Bininda-Emonds, O.R.P., Mace, G.M., and Wayne, R.K. 2000. Considering evolutionary processes in conservation biology. Trends Ecol. Evol. 15: 290-295.

Dymond, J.R. 1932. The trout and other game fishes of British Columbia. Department of Fisheries, Ottawa, Ont.

Farrell, A.P., Johansen, J.A., Seffensen, J.F., Moyes, C.D., West, T.G., and Suarez, R.K. 1990. Effects of exercise training and coronary ablation on swimming performance, heart size, and cardiac enzymes in rainbow trout, Oncorhynchus mykiss. Can. J. Zool. 68: 1174-1179.

Fleming, I.A., Jonsson, B., and Gross, M.R. 1994. Phenotypic divergence of sea-ranched, farmed, and wild salmon. Can. J. Fish. Aquat. Sci. 51: 2808-2824.

Fraser, D.F. 2000. Species at the edge: the case for listing of "peripheral" species. In At Risk - Proceedings of a Conference on the Biology and Management of Species and Habitats at Risk. Vol. 1, 15-19 February 1999, University College of the Cariboo, Kamloops, B.C. Edited by L.M. Darling. B.C. Ministry of Environment, Lands, and Parks, Victoria, B.C. pp. 49-53.

Fryer, G., and Iles, T.D. 1972. The cichlid fishes of the Great Lakes of Africa. Oliver and Boyd, Edinburgh, Scotland.

García, L.V. 2003. Controlling the false discovery rate in ecological research. Trends Ecol. Evol. 18: 553-554.

Gould, S.J., and Johnston, R.F. 1972. Geographic variation. Annu. Rev. Ecol. Syst. 3: 457-498.

Hard, J.J. 1995. A quantitative genetic perspective on the conservation of intraspecific diversity. In Evolution and the aquatic ecosystem: defining unique units in population conservation. Edited by J.L. Nielsen and D.A. Powers. Am. Fish. Soc. Symp. 17: 304-328.

Hilton, G.M., Lilliendahl, K., Solmundsson, J., Houston, D.C., and Furness, R.W. 2000. Geographical variation in the size of body organs in seabirds. Funct. Ecol. 14: 369-379.

Imre, I., McLaughlin, R.L., and Noakes, D.L.G. 2002. Phenotypic plasticity in brook charr (Salvelinus fontinalis): changes in caudal fin induced by water flow. J. Fish Biol. 61: 1171-1181.

Irvine, J.R. 1978. The Gerrard rainbow trout of Kootenay Lake, British Columbia - a discussion of their life history with management, research and enhancement recommendations. Prov. B.C. Fish. Manag. Rep. No. 72.

Johannes, R.E., and Larkin, P.A. 1961. Competition for food between redside shiners (Richardsonius balteatus) and rainbow trout (Salmo gairdneri) in two British Columbia lakes. J. Fish. Res. Board Can. 18: 203-220.

Jordan, D.S., Evermann, B.W., and Clark, H.W. 1930. Check list of the fishes and fishlike vertebrates of North and Middle America north of the northern boundary of Venezuala and Columbia. Report of the United States Fish Commission for 1928. US Fish Commission, Washington, D.C.

Kramer, D.L., and Bryant, M.J. 1995. Intestine length in the fishes of a tropical stream: 2. Relationships to diet - the long and short of a convoluted issue. Environ. Biol. Fishes, 42: 129-141.

Lavin, P.A., and McPhail, J.D. 1986. Adaptive divergence of trophic phenotype among freshwater populations of threespine stickleback (Gasterosteus aculeatus). Can. J. Fish. Aquat. Sci. 43: 2455-2463.

Lindsey, C.C. 1978. Form, function, and locomotory habits in fish. In Fish physiology. Vol. VII. Edited by W.S. Hoar and D.J. Randall. Academic Press, New York. pp. 1-100.

Lindsey, C.C. 1981. Stocks as chameleons: plasticity in gills rakers of coregonid fishes. Can. J. Fish. Aquat. Sci. 38: 1497-1506.

Littell, R.C., Milliken, G.A., Stroup, W.W., and Wolfinger, R.D. 1996. SAS system for mixed models. SAS Institute Inc., Cary, N.C.

Magnan, P. 1988. Interactions between brook trout and nonsalmonid species: ecological shift, morphological shift, and their impact on zooplankton communities. Can. J. Fish. Aquat. Sci. 45: 999-1009.

Magnan, P., and Stevens, E.D. 1992. Pyloric caecal morphology of brook charr, Salvelinus fontinalis, in relation to diet. Environ. Biol. Fishes, 36: 2856-2865. 
Manel, S., Schwartz, M.K., Luikart, G., and Taberlet, P. 2003. Landscape genetics: combining landscape ecology and population genetics. Trends Ecol. Evol. 18: 189-197.

Mayr, E. 1963. Animal species and evolution. The Belknap Press, Cambridge, UK.

McCusker, M.R., Parkinson, E.A., and Taylor, E.B. 2000. Mitochondrial DNA variation in rainbow trout (Oncorhynchus mykiss) across its native range: testing biogeographical hypotheses and their relevance to conservation. Mol. Ecol. 9: 20892108 .

McDowell, R.M. 1998. Phylogenetic relationships and ecomorphological divergence in sympatric and allopatric species of Paragalaxias (Teleostei: Galaxiidae) in high elevation Tasmanian lakes. Environ. Biol. Fishes, 53: 235-257.

McLaughlin, R.L., and Grant, J.W.A. 1994. Morphological and behavioural differences among recently-emerged brook charr, Salvelinus fontinalis, foraging in slow- vs. fast-running water. Environ. Biol. Fishes, 39: 289-300.

Mottley, C.McC. 1936a. The classification of the rainbow trout of British Columbia. Biol. Board Can. Prog. Rep. Pac. Biol. Stn. Pac. Fish. Stn. 27: 3-5.

Mottley, C.McC. 1936b. A biometrical study of the Kamloops trout of Kootenay Lake, Salmo kamloops Jordan. J. Biol. Board Can. 2: 359-377.

Northcote, T.G. 1997. Potamodromy in Salmonidae - living and moving in the fast lane. N. Am. J. Fish. Manag. 17: 1029-1045.

Northcote, T.G., and Hartman, G.F. 1988. The biology and significance of stream trout populations (Salmo spp.) living above and below waterfalls. Pol. Arch. Hydrobiol. 35: 409-442.

Pakkasmaa, S., and Piironen, J. 2001. Water velocity shapes juvenile salmonids. Evol. Ecol. 14: 721-730.

Pearcy, W.G. 1992. Ocean ecology of north Pacific salmonids. University of Washington, Seattle, Wash.

Pritchard, J.R., and Schluter, D. 2001. Declining interspecific competition during character displacement: summoning the ghost of competition past. Evol. Ecol. Res. 3: 209-220.

Proulx, R., and Magnan, P. 2004. Contribution of phenotypic plasticity and heredity to trophic polymorphism of lacustrine brook charr (Salvelinus fontinalis M.). Evol. Ecol. Res. 6: 503-522.

Quinn, G.P., and Keough, M.J. 2002. Experimental design and data analysis for biologists. Cambridge University Press, Cambridge, UK.

Riddell, B.E., and Leggett, W.C. 1981. Evidence of an adaptive basis for geographic variation in body morphology and time of downstream migration of juvenile Atlantic salmon (Salmo salar). Can. J. Fish. Aquat. Sci. 38: 308-320.

Riddell, B.E., Leggett, W.C., and Saunders, R.L. 1981. Evidence of adaptive polygenic variation between two populations of Atlantic salmon (Salmo salar) native to tributaries of the S.W. Miramichi River, N.B. Can. J. Fish. Aquat. Sci. 38: 321-333.

Robinson, B.W., and Parsons, K.J. 2002. Changing times, spaces, and faces: tests and implications of adaptive morphological plasticity in the fishes of northern postglacial lakes. Can. J. Fish. Aquat. Sci. 59: 1819-1833.

Robinson, B.W., and Wilson, D.S. 1994. Character release and displacement in fishes: a neglected literature. Am. Nat. 144: 596-627.

Sanderson, S.L., Cheer, A.Y., Goodrich, J.S., Graziano, J.D., and Callan, W.T. 2001. Crossflow filtration in suspension-feeding fishes. Nature (Lond.), 412: 439-441.

SAS Institute Inc. 1999. SAS online document, version 8. SAS Institute Inc., Cary, N.C.

Schluter, D., and McPhail, J.D. 1993. Character displacement and replicate adaptive radiation. Trends Ecol. Evol. 8: 197-200.
Scudder, G.G.E. 1989. The adaptive significance of marginal populations: a general perspective. In Proceedings of the National Workshop on Effects of Habitat Alteration on Salmonid Stocks. Edited by C.D. Levings, L.B. Holtby, and M.A. Henderson. Can. Spec. Publ. Fish. Aquat. Sci. No. 105. pp. 180-185.

Skúlason, S., Noakes, D.L.G., and Snorrason, S.S. 1989. Ontogeny of trophic morphology in four sympatric morphs of arctic charr Salvelinus alpinus in Thingvallavatn, Iceland. Biol. J. Linn. Soc. 38: 281-301.

Smith, S.B. 1969. Reproductive isolation in summer and winter races of anadromous trout. In Symposium on salmon and trout in streams, 22-24 February 1968, The University of British Columbia, Vancouver, B.C. H.R. MacMillan Lectures in Fisheries. Edited by T.G. Northcote. Institute of Fisheries, The University of British Columbia, Vancouver, B.C.

Smith, T.B., and Skùlason, S. 1996. Evolutionary significance of resource polymorphisms in fish, amphibians and birds. Annu. Rev. Ecol. Syst. 27: 111-133.

Snorrason, S., Skúlason, S., Jonsson, B., Malmquist, H.J., Jónasson, P.M., Sandlund, O.T., and Lindem, T. 1994. Trophic specialization in Arctic charr Salvelinus alpinus (Pisces; Salmonidae): morphological divergence and ontogenetic niche shifts. Biol. J. Linn. Soc. 52: 1-18.

Stearley, R.F. 1993. Historical ecology of Salmoninae, with special reference to Oncorhynchus. In Systematics, historical ecology, and North American freshwater fishes. Edited by R.L. Mayden. Stanford University Press, Stanford, Calif. pp. 622-658.

Sultan, S.E. 1995. Phenotypic plasticity and plant adaptation. Acta Bot. Neerl. 44: 363-275.

Swain, D.P., and Holtby, L.B. 1989. Differences in morphology and behavior between juvenile coho salmon (Oncorhynchus kisutch) rearing in a lake and in its tributary stream. Can. J. Fish. Aquat. Sci. 46: 1406-1414.

Taylor, E.B. 1991. A review of local adaptation in Salmonidae, with particular reference to Pacific salmon and Atlantic salmon. Aquaculture, 98: 185-207.

Taylor, E.B. 1999. Species pairs of north temperate freshwater fishes: evolution, taxonomy, and conservation. Rev. Fish Biol. Fish. 9: 299-334.

Taylor, E.B., and Haas, G.R. 1996. Maintaining a species tapestry: a plan for the conservation of genetic diversity in British Columbia rainbow trout, Oncorhynchus mykiss. Province of British Columbia, Ministry of Environment, Lands and Parks, Vancouver, B.C. Fish. Tech. Circ. No. 99.

Taylor, E.B., and McPhail, J.D. 1985. Variation in body morphology among British Columbia populations of coho salmon, Oncorhynchus kisutch. Can. J. Fish. Aquat. Sci. 42: 2020-2028.

Thorpe, R.S. 1976. Biometric analysis of geographic variation and racial affinities. Biol. Rev. 51: 407-452.

Tipping, J.M. 1991. Heritability of age at maturity in steelhead. N. Am. J. Fish. Manag. 11: 105-108.

Turesson, G. 1922. The species and the variety as ecological units. Hereditas, 3: 100-113.

Wainwright, P.C., and Richard, B.A. 1995. Predicting patterns of prey use from morphology of fishes. Environ. Biol. Fishes, 44: 97-113.

Waples, R.S. 1995. Evolutionary significant units and the conservation of biological diversity under the Endangered Species Act. In Evolution and the aquatic ecosystem: defining unique units in population conservation. Edited by J.L. Nielsen and D.A. Powers. Am. Fish. Soc. Symp. 17: 8-27.

Waples, R.S., Gustafson, R.G., Weitkamp, L.A., Myers, J.M., Johnson, O.W., Busby, P.J., Hard, J.J., Bryant, G.J., Waknitz, F.W., Neely, K., Teel, D., Grant, W.S., Winans, G.A., Phelps, S., Mar- 
shall, A., and Baker, B.M. 2002. Characterizing diversity in salmon from the Pacific Northwest. J. Fish Biol. 59(Suppl. A): 141.

Watters, J.V., Lema, S.C., and Nevitt, G.A. 2003. Phenotype management: a new approach to habitat restoration. Biol. Conserv. 112: 435-445.

Webb, P.W. 1975. Hydrodynamics and energetics of fish propulsion. Bull. Fish. Res. Board Can. No. 190.
Webb, P.W. 1978. Hydrodynamics: nonscrombroid fish. In Fish physiology. Vol. VII. Edited by W.S. Hoar and D.J. Randall. Academic Press, New York. pp. 190-237.

Withler, I.L. 1966. Variability in life history characteristics of anadromous trout (Salmo gairdneri) along the Pacific coast of North America. J. Fish. Res. Board Can. 23: 365-393.

\section{Appendix A}

Table A1. Location of sampling sites, ecotypic category, and fish species composition of water bodies used in morphological comparisons of rainbow trout (Oncorhynchus mykiss) populations.

\begin{tabular}{|c|c|c|c|c|c|c|}
\hline Water body ${ }^{a}$ & $\begin{array}{l}\text { Population } \\
\text { No. }\end{array}$ & Ecotype & Fish species present ${ }^{c}$ & $\begin{array}{l}\text { Sample } \\
\text { size }\end{array}$ & $\begin{array}{l}\text { Longitude } \\
\left({ }^{\circ} \mathrm{W}\right)\end{array}$ & $\begin{array}{l}\text { Latitude } \\
\left({ }^{\circ} \mathrm{N}\right)\end{array}$ \\
\hline Thutade Lake & 1 & Mixed species 3 & $\mathrm{RB}, \mathrm{KO}, \mathrm{BT}, \mathrm{MW}, \mathrm{LSU}, \mathrm{CC}$ & 18 & $126^{\circ} 50.6^{\prime}$ & $56^{\circ} 50.8^{\prime}$ \\
\hline Tatlatui Lake & 2 & Solitary & $\mathrm{RB}$ & 50 & $127^{\circ} 15.3^{\prime}$ & $56^{\circ} 55.8^{\prime}$ \\
\hline Jacobie Lake & 4 & Mixed species 1 & $\mathrm{RB}, \mathrm{LSU}$ & 50 & $121^{\circ} 45.2^{\prime}$ & $52^{\circ} 30.5^{\prime}$ \\
\hline Tzenziacut Lake & 5 & Mixed species 3 & $\mathrm{RB}, \mathrm{LKC}, \mathrm{LNC}$ & 50 & $122^{\circ} 50.2^{\prime}$ & $52^{\circ} 35.8^{\prime}$ \\
\hline Canyon Creek & 8 & Headwater & $\mathrm{RB}, \mathrm{BT}, \mathrm{CT}$ & 35 & $126^{\circ} 45.6^{\prime}$ & $54^{\circ} 40.7^{\prime}$ \\
\hline Division Lake & 9 & Mixed species 1 & RB, LSU, CSU & 50 & $125^{\circ} 35.9^{\prime}$ & $54^{\circ} 20.2^{\prime}$ \\
\hline Nellian Lake & 10 & Mixed species 3 & RB, LSU, LKC & 50 & $125^{\circ} 40.8^{\prime}$ & $54^{\circ} 20.6^{\prime}$ \\
\hline Hannay Lake & 11 & Mixed species 3 & RB, LSU, WSU, LKC, BB & 50 & $125^{\circ} 00.3^{\prime}$ & $54^{\circ} 15.6^{\prime}$ \\
\hline Kuyakuz Lake & 12 & Mixed species 3 & RB, KO, LSU, LKC, MW, CA, NSC & 50 & $124^{\circ} 35.0^{\prime}$ & $53^{\circ} 05.7^{\prime}$ \\
\hline Lucas Lake & 13 & Mixed species 3 & $\begin{array}{l}\text { RB, KO, LSU, WSU, LKC, MW, CA, NSC, } \\
\text { BB }\end{array}$ & 50 & $125^{\circ} 10.0^{\prime}$ & $53^{\circ} 30.7^{\prime}$ \\
\hline Bayonne Creek & 16 & Headwater & $\mathrm{RB}$ & 35 & $116^{\circ} 55.5^{\prime}$ & $49^{\circ} 05.6^{\prime}$ \\
\hline Clearwater River & 17 & Large river & $\mathrm{RB}, \mathrm{CH}$ & 50 & $120^{\circ} 10.2^{\prime}$ & $51^{\circ} 55.0^{\prime}$ \\
\hline Coldwater River & 18 & Anadromous & $\mathrm{RB}, \mathrm{CH}, \mathrm{CC}$ & 35 & $120^{\circ} 50.6^{\prime}$ & $49^{\circ} 45.7^{\prime}$ \\
\hline Nahmint River & 19 & Anadromous & $\mathrm{RB}, \mathrm{CO}, \mathrm{CH}$ & 35 & $124^{\circ} 55.5^{\prime}$ & $49^{\circ} 05.2^{\prime}$ \\
\hline Memekay River & 20 & Anadromous & $\mathrm{RB}, \mathrm{CO}, \mathrm{DV}$ & 35 & $124^{\circ} 45.6^{\prime}$ & $50^{\circ} 05.9^{\prime}$ \\
\hline Tsitika River & 21 & Anadromous & $\mathrm{RB}, \mathrm{CO}, \mathrm{CH}, \mathrm{CT}, \mathrm{PL}$ & 35 & $126^{\circ} 25.3^{\prime}$ & $50^{\circ} 15.9^{\prime}$ \\
\hline Nimpkish River & 22 & Anadromous & $\mathrm{RB}, \mathrm{CO}, \mathrm{CH}$ & 35 & $126^{\circ} 35.1^{\prime}$ & $50^{\circ} 10.3^{\prime}$ \\
\hline Gold River & 23 & Anadromous & $\mathrm{RB}, \mathrm{CO}, \mathrm{CH}$ & 35 & $126^{\circ} 05.1^{\prime}$ & $49^{\circ} 50.2^{\prime}$ \\
\hline Heber River & 24 & Anadromous & $\mathrm{RB}, \mathrm{CO}, \mathrm{CH}$ & 35 & $126^{\circ} 00.2^{\prime}$ & $49^{\circ} 45.5^{\prime}$ \\
\hline English Lake & 25 & Mixed species 2 & RB, RSC, NSC & 50 & $120^{\circ} 35.8^{\prime}$ & $51^{\circ} 30.9^{\prime}$ \\
\hline Fish Lake & 26 & Solitary & $\mathrm{RB}$ & 50 & $123^{\circ} 35.3^{\prime}$ & $51^{\circ} 25.4^{\prime}$ \\
\hline Chaunigan Lake & 27 & Mixed species 2 & $\mathrm{RB}, \mathrm{RSC}$ & 50 & $123^{\circ} 55.7^{\prime}$ & $51^{\circ} 30.8^{\prime}$ \\
\hline Blanchet Lake & 35 & Mixed species 3 & $\mathrm{RB}, \mathrm{LNC}, \mathrm{LKC}$ & 50 & $126^{\circ} 18.0^{\prime}$ & $53^{\circ} 24.2^{\prime}$ \\
\hline Small Lake & 36 & Mixed species 3 & $\mathrm{RB}, \mathrm{LNC}, \mathrm{LKC}$ & 50 & $126^{\circ} 23.1^{\prime}$ & $53^{\circ} 22.3^{\prime}$ \\
\hline Large Lake & 37 & Mixed species 3 & RB, LNC, LKC & 50 & $126^{\circ} 25.3^{\prime}$ & $53^{\circ} 21.2^{\prime}$ \\
\hline Tlutilias Lake & 38 & Mixed species 3 & RB, LSC, LNC, LKC & 50 & $126^{\circ} 14.4^{\prime}$ & $53^{\circ} 24.5^{\prime}$ \\
\hline Grizzly Lake & 39 & Solitary & $\mathrm{RB}$ & 50 & $126^{\circ} 22.6^{\prime}$ & $53^{\circ} 24.5^{\prime}$ \\
\hline Glatheli Lake & 40 & Mixed species 3 & RB, MW, LNC, LSC, LKC & 50 & $126^{\circ} 20.1^{\prime}$ & $53^{\circ} 38.2^{\prime}$ \\
\hline Unamed Lake & 41 & Mixed species 3 & RB, KO, MW, LSC, LNC, SQ, LKC & 50 & $126^{\circ} 28.3^{\prime}$ & $53^{\circ} 37.0^{\prime}$ \\
\hline
\end{tabular}


Table A1 (concluded).

\begin{tabular}{|c|c|c|c|c|c|c|}
\hline Water body ${ }^{a}$ & $\begin{array}{l}\text { Population } \\
\text { No. }{ }^{b}\end{array}$ & Ecotype & Fish species present ${ }^{c}$ & $\begin{array}{l}\text { Sample } \\
\text { size }\end{array}$ & $\begin{array}{l}\text { Longitude } \\
\left({ }^{\circ} \mathrm{W}\right)\end{array}$ & $\begin{array}{l}\text { Latitude } \\
\left({ }^{\circ} \mathrm{N}\right)\end{array}$ \\
\hline Michel Lake & 42 & Mixed species 3 & RB, LSC, LNC, KO, NSC, MW & 50 & $126^{\circ} 29.8^{\prime}$ & $53^{\circ} 35.8^{\prime}$ \\
\hline Lake 43 & 43 & Mixed species 3 & $\mathrm{RB}, \mathrm{LNC}, \mathrm{LKC}$ & 50 & $126^{\circ} 20.2^{\prime}$ & $53^{\circ} 36.6^{\prime}$ \\
\hline Ghitzeli Lake & 45 & Mixed species 3 & $\mathrm{RB}, \mathrm{KO}, \mathrm{LNC}, \mathrm{LSC}, \mathrm{NSC}, \mathrm{LKC}$ & 50 & $126^{\circ} 15.4^{\prime}$ & $53^{\circ} 38.0^{\prime}$ \\
\hline Theleteban Lake & 46 & Mixed species 3 & $\mathrm{RB}, \mathrm{KO}, \mathrm{LNC}, \mathrm{LSC}, \mathrm{NSC}$ & 50 & $126^{\circ} 13.1^{\prime}$ & $53^{\circ} 35.3^{\prime}$ \\
\hline Morgan Lake & 49 & Mixed species 3 & $\mathrm{RB}, \mathrm{LKC}, \mathrm{LNC}$ & 50 & $126^{\circ} 19.9^{\prime}$ & $53^{\circ} 30.0^{\prime}$ \\
\hline Nutli Lake & 50 & Mixed species 3 & $\mathrm{RB}, \mathrm{LKC}, \mathrm{LNC}$ & 50 & $126^{\circ} 16.7^{\prime}$ & $53^{\circ} 29.5^{\prime}$ \\
\hline Twinkle Lake & 51 & Mixed species 3 & RB, LSC, LNC, NSC, MW, BT, CC & 50 & $127^{\circ} 01.1^{\prime}$ & $53^{\circ} 48.5^{\prime}$ \\
\hline Needle Lake & 52 & Mixed species 3 & $\mathrm{RB}, \mathrm{KO}, \mathrm{SU}$ & 50 & $126^{\circ} 58.4^{\prime}$ & $53^{\circ} 48.9^{\prime}$ \\
\hline Lake Unamed & 53 & Mixed species 3 & $\mathrm{RB}, \mathrm{SU}, \mathrm{LKC}$ & 50 & $127^{\circ} 06.3^{\prime}$ & $53^{\circ} 48.2^{\prime}$ \\
\hline Upstream Lake & 54 & Mixed species 3 & $\mathrm{RB}, \mathrm{SU}, \mathrm{LKC}$ & 50 & $126^{\circ} 55.9^{\prime}$ & $53^{\circ} 48.2^{\prime}$ \\
\hline Horseshoe Lake & 57 & Mixed species 3 & $\mathrm{RB}, \mathrm{MW}, \mathrm{KO}, \mathrm{LNC}, \mathrm{LSC}$ & 50 & $126^{\circ} 50.4^{\prime}$ & $53^{\circ} 50.4^{\prime}$ \\
\hline No Man Creek & 58 & Headwater & $\mathrm{RB}$ & 50 & $126^{\circ} 38.0^{\prime}$ & $53^{\circ} 49.1^{\prime}$ \\
\hline Chelaslie River & 59 & Large river & $\mathrm{RB}$ & 50 & $125^{\circ} 55.1^{\prime}$ & $53^{\circ} 28.7^{\prime}$ \\
\hline Star Lake & 60 & Mixed species 1 & $\mathrm{RB}, \mathrm{SU}$ & 50 & $125^{\circ} 52.7^{\prime}$ & $53^{\circ} 31.0^{\prime}$ \\
\hline Unamed Creek & 61 & Headwater & $\mathrm{RB}$ & 50 & $125^{\circ} 52.6^{\prime}$ & $53^{\circ} 27.4^{\prime}$ \\
\hline
\end{tabular}

${ }^{a}$ Geographic place names are from Canadian topographic maps of British Columbia. If no official place name was available from the map, we assigned an unofficial place name.

${ }^{b}$ Refer to locations in Fig. 1.

${ }^{c} \mathrm{RB}$, rainbow trout (Oncorhynchus mykiss); KO, kokanee (Oncorhynchus nerka); LSC, largescale sucker (Catostomus macrocheilus); LNC, longnose sucker (Catostomus catostomus); LKC, lake chub (Couesius plumbeus); RSC, redside shiner (Richardsonius balteatus); BT, bull trout (Salvelinus confluentus); DV, Dolly Varden (Salvelinus malma); CO, coho salmon (Oncorhynchus kisutch); CH, chinook salmon (Oncorhynchus tshawytscha); CT, cutthroat trout (Oncorhynchus clarki); CA, prickly sculpin (Cottus asper); CB, mottled sculpin (Cottus bairdi); CC, unknown sculpin species (Cottus sp.); MW, mountain whitefish (Prosopium williamsoni); BB, burbot (Lota lota); SU, unknown sucker species (Catostomus spp.); NSC, northern squawfish (Ptycholeilus oregonensis); PL, Pacific lamprey (Lampetra tridentata). 